\title{
State budget transfers to Health Insurance to expand coverage to people outside formal sector work in Latin America
}

Inke Mathauer $^{1 *}$ and Thorsten Behrendt ${ }^{2}$

\begin{abstract}
Background: Contributory social health insurance for formal sector employees only has proven challenging for moving towards universal health coverage (UHC). This is because the informally employed and the poor usually remain excluded. One way to expand UHC is to fully or partially subsidize health insurance contributions for excluded population groups through government budget transfers. This paper analyses the institutional design features of such government subsidization arrangements in Latin America and assesses their performance with respect to UHC progress. The aim is to identify UHC conducive institutional design features of such arrangements.

Methods: A literature search provided the information to analyse institutional design features, with a focus on the following aspects: eligibility/enrolment rules, financing and pooling arrangements, and purchasing and benefit package design. Based on secondary data analysis, UHC progress is assessed in terms of improved population coverage, financial protection and access to needed health care services.

Results: Such government subsidization arrangements currently exist in eight countries of Latin America (Bolivia, Chile, Colombia, Costa Rica, Dominican Republic, Mexico, Peru, Uruguay). Institutional design features and UHC related performance vary significantly. Notably, countries with a universalist approach or indirect targeting have higher population coverage rates. Separate pools for the subsidized maintain inequitable access. The relatively large scopes of the benefit packages had a positive impact on financial protection and access to care.

Discussion and Conclusion: In the long term, merging different schemes into one integrated health financing system without opt-out options for the better-off is desirable, while equally expanding eligibility to cover those so far excluded. In the short and medium term, the harmonization of benefit packages could be a priority. UHC progress also depends on substantial supply side investments to ensure the availability of quality services, particularly in rural areas. Future research should generate more evidence on the implementation process and impact of subsidization arrangements on UHC progress.
\end{abstract}

Keywords: Universal health coverage, Vulnerable population groups, Government subsidization of health insurance, Financial protection

\footnotetext{
* Correspondence: mathaueri@who.int

${ }^{1}$ Department of Health Systems Governance and Financing, World Health

Organization, Avenue Appia, 1211 Geneva, Switzerland

Full list of author information is available at the end of the article
} 


\section{Background}

Latin America has a long social health insurance (SHI) tradition. This had resulted in segmented systems, in which a SHI scheme covers almost exclusively formal sector employees only, and private health insurances those who can afford it. The "rest" of the population, i.e. those in the informal sector, have thereby usually resorted to government health services provided by the Ministry of Health $(\mathrm{MOH})$, resulting in segmented service delivery structures as well [1]. Progressing towards UHC has proven to be difficult in many of the countries with a SHI system, particularly as to the inclusion of population groups outside the formal sector [1-4]. Various vulnerable population groups cannot afford to pay contributions on their own, because they have no income, a very low income, or a very unsteady income.

In fact, there is an emerging consensus among countries on the need to reform health financing systems in order to accelerate progress towards Universal Health Coverage (UHC). UHC means that everyone can access quality health services without facing financial hardship as a result [5]. The 2014 Pan American Health Organization (PAHO) strategy for universal access to health and UHC acknowledges that there are many different ways to progress towards UHC and that each country will need to establish its own action plan, taking into account its social, economic, political, legal, historical and cultural context as well as its priorities and current and future health challenges [6]. The health financing reform steps taken by countries in Latin America during the last decades toward these objectives reflect this diversity [7].

While not the only UHC extension approach, a trend can be seen in Latin America however, in that several countries have moved towards UHC and expanded coverage to people outside the formal sector by transforming the SHI logic that is based on entitlement against mandatory contributions for formal sector employees. These countries have done so by subsidizing health insurance type arrangements through state budget transfers, which serves to cover non-contributing individuals outside the formal sector. This allows to delink entitlements from contributions [8]. Here, a health insurance type scheme is understood as a health financing scheme that usually starts from an insurance logic: it provides coverage of an explicit benefit package to defined and entitled individuals that are identified and affiliated, in exchange for explicit or implicit contributions paid by or on behalf of these. Notably, this type of health financing mechanism and expansion strategy towards UHC is found in countries with strongly varying economic and fiscal situations.

The existing body of literature provides country focused health system reform studies. Specifically, the Lancet 2014 paper series on UHC in Latin America includes a cross-country overview of health systems reforms aiming at UHC in Latin America [9, 10]. Building upon these, this paper fills a gap in the literature: it gives an overview of such arrangements for Latin America and specifically analyses institutional design features of subsidization of health insurance type schemes and their potential contribution to progress towards UHC, with the aim of deriving policy lessons of what works and what does not. The institutional design of a financing arrangement is understood as policy, legal or regulatory specifications that define this arrangement's structure and the way it operates. Furthermore, this paper is part of a series of regional studies on Europe (Vilcu/Mathauer 2016 for Eastern-European high-income countries [11] and Mathauer et al. [14] on low- and middle-income countries of the European WHO Region [12]), Asia 2016 (Vilcu et al. [13]) and Africa (Mathauer et al. [14]).

The next section presents the methodology and analytical framework applied. The Results section assesses the institutional design features of the schemes as well as progress towards UHC. The Discussion explores possible effects of key institutional design features on $\mathrm{UHC}$ and related challenges, followed by a Conclusion.

\section{Methods}

This study chose to consider those Latin American countries with Romance languages, thus excluding the Dutch or English speaking countries and Caribbean island states, most of which with relatively small populations, because they have a different history. In a first step, all countries in this language group were considered if the Global Health Expenditure Database reported social health insurance (SHI) expenditure (or termed social security expenditure for health in WHO's Global Health Expenditure Database). The second step consisted in identifying countries with a health insurance type arrangement that covers people outside the formal sector by using state budget transfers. Thirdly, countries without SHI expenditure were screened to see whether there is a country with a government subsidization arrangement, but without SHI expenditure. This last step did not expand the list of countries included in this study. Altogether, these study inclusion criteria rendered eight countries to be assessed here, namely Bolivia, Chile, Colombia, Costa Rica, Dominican Republic, Mexico, Peru and Uruguay. As such, countries with a budget funded population-wide national health care system such as Brazil or Cuba, or countries with social health insurance for formal sector employees, but without subsidized enrolment for people outside formal sector work, like El Salvador were excluded.

The study is based on a comprehensive literature search from 1990 to December 2015. Data bases and search engines used in English included Scopus, Science 
Direct, PubMed, JSTOR and Google, and Scielo and CLASE for Spanish material. In Google, the first five pages, with 10 results per page, were considered, excluding commercial pages and ads, news press or other irrelevant pages. The search terms used for collecting information on institutional design features included: health system OR budget transfer OR health subsidization OR health subsidy OR health insurance OR health vulnerable AND country name AND/OR scheme name. The data search for information on progress towards UHC was based on the following terms: impact health insurance OR catastrophic health expenditure OR impoverish* health care OR out-of-pocket payment OR financial protection OR access health OR utilization health care OR health insurance coverage OR universal coverage OR impact OR effects AND country AND/OR scheme name. Additionally, data for the progress assessment was collected from the WHO's Global Health Expenditure Database [15], government and country insurance fund webpages. Thus, the study is based on a literature review and analysis of secondary databases. This search strategy generated 70 sources for country information from peer-reviewed journals, studies and reports from United Nations organisations (primarily World Bank, ILO and WHO) and research institutes as well as from reports and legal provisions published by governmental organisations. Most of the studies found were country health financing analyses to review reform experiences, but no studies with explicit impact evaluation design were found.

For each country, respective titles identified through the search process were reviewed, and if found to be relevant the abstract or executive summary was read. If this suggested that the publication could provide information on the institutional design or UHC related indicators, the full publication was assessed. Since the search generated several publications for each country, this allowed for cross-check and triangulation to gather valid and reliable (largely descriptive) information on both institutional design aspects as well as UHC related progress data. Officially published data (e.g. from government) and data found in peer-reviewed journals were used as the preferred source when incoherences were found across several studies. Where in doubt about data, the respective information was checked with WHO country experts. The analytical framework outlined further below guided the information extraction process from the literature, as well as data compilation and organisation.

To identify plausible contributions and patterns of institutional design features in relation to UHC progress, we plotted the improvements in UHC related progress indicators against the respective institutional design features for the eight countries using the analytical framework explained below. Multiple country sources helped to capture changes over time. Where data points of different years were available, progress towards UHC over time and in relation to changes in institutional design could be assessed, however, it was often difficult to do so due to scarce data availability for most of the indicators. This is a limitation to this study, and in view of the multiple factors affecting progress towards UHC, this analysis is of explorative nature.

The paper's analytical framework to assess the institutional design features of budget transfer arrangements starts from the three health financing functions described in Kutzin [16] and looks specifically at the following features:

\section{Revenue raising}

- Eligibility and enrolment arrangements

- Financing arrangements

Pooling

- Pooling architecture

Purchasing

- Benefit package design and type of providers covered

- Cost-sharing arrangements

- Provider payment methods and purchasing arrangements

The detailed analytical framework, which was developed for these regional studies [11-14] is found in Table 1, which specifies the institutional design aspects and outlines how these potentially relate to progress toward UHC. Progress towards UHC refers to improvements in population coverage (here specifically focusing on reported enrolment rates), in financial protection and in access to care. The design features and progress indicators are defined and explained in more detail in the next section, but just to emphasise here that checking whether the poor and lower income quintiles benefit at least proportionally is important for equitable progress towards UHC. It is also important to note that subsidized enrolment and coverage in such schemes is only one possible and plausible factor among several to explain improvements in population coverage, the level of financial protection and access to care of subsidized beneficiaries. The overall economic and fiscal situation is thereby decisive in expanding fiscal space that can be used for state budget transfers to subsidize health insurance contributions. The following Results section and tables present the most recent information available.

\section{Results}

Country and Scheme Overview

Since the start of the millennium, economic growth, changing public demands for the right to health and 


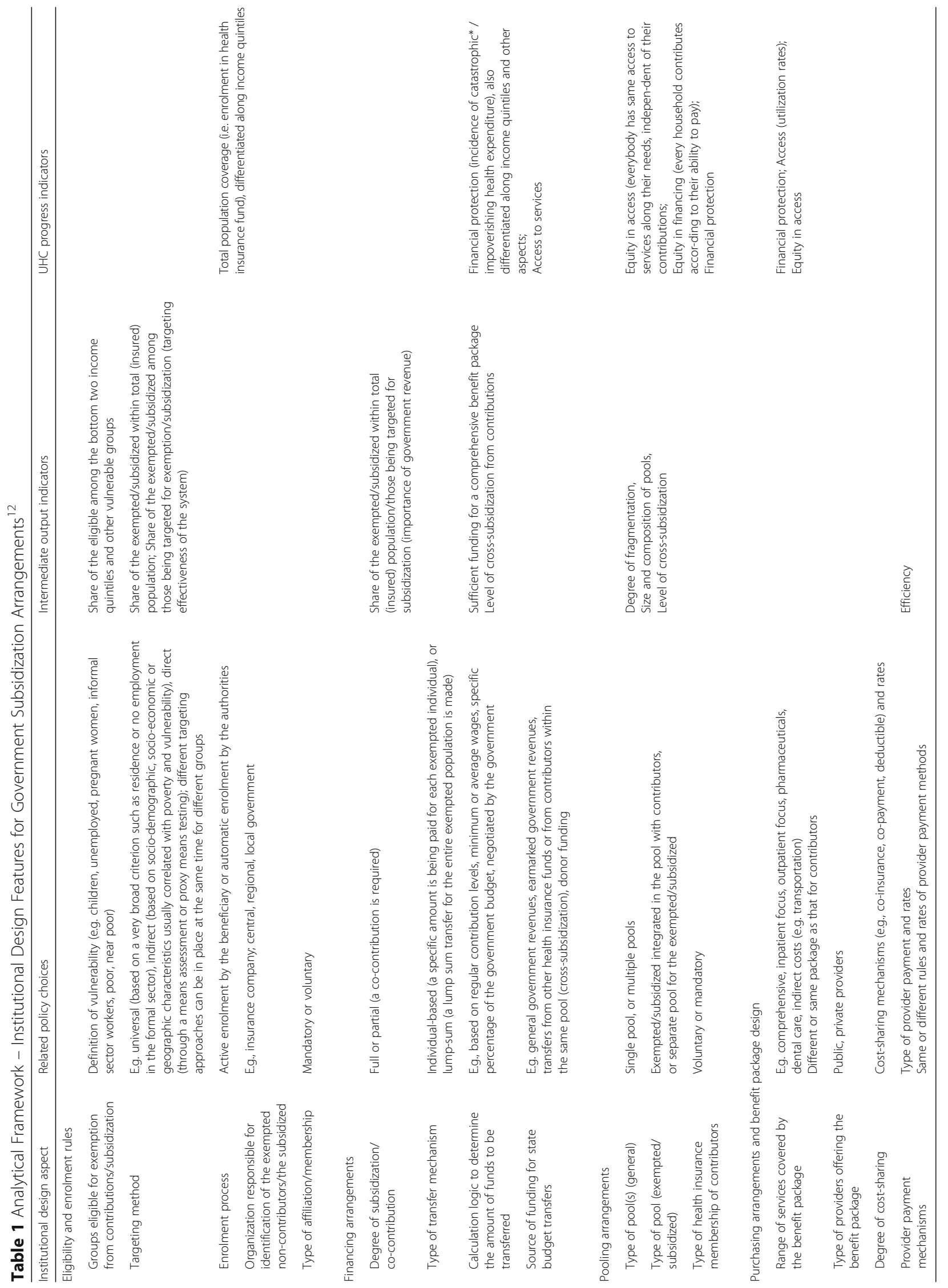


an extended process of democratization across the region have created windows of opportunity for health financing reforms [9, 17]. Eight countries have now subsidization arrangements. The Dominican Republic, Peru, Mexico, Bolivia and Uruguay have introduced a subsidization arrangement by providing state budget transfers to health insurance type schemes in the 2000s. In contrast, the subsidization arrangements of Chile, Costa Rica and Colombia had already long been in place by then, since 1973, 1979, and 1993 respectively (see Table 2, Column 2). In the case of Chile, a broader and explicit benefit package, called AUGE ("Universal Access to Explicit Guarantees") came in place in 2003, expanding service coverage and improving coverage equity. These insurance type arrangements were set up with a purchaser-provider split in all countries other than Bolivia, Mexico and Uruguay. All countries studied belonged to the group of upper middle-income countries at the time of the implementation of the subsidization schemes, with the exception of Bolivia, which is a lower-middle income country. Chile and Uruguay are high income countries since 2012 as per the World Bank classification [18].

\section{Definition of eligible groups}

Eligibility rules reflect a country's understanding of which population groups are considered 'vulnerable' with regard to health care access. Hence, how eligibility is defined will affect the proportion of the population ultimately subsidized, and who will remain uncovered. In the eight studied Latin American countries, a wide range of different vulnerability and eligibility criteria is found to determine who benefits from subsidization via health insurance type schemes (see Table 3, column 2). Poverty and low income are the most frequent criteria. Except for Bolivia and Uruguay, countries classify the population into (income) segments as a basis to determine eligibility for benefiting from subsidized coverage. The poorest are in all countries entitled to full subsidization, with the exception of Bolivia where the poor are not specifically defined as an eligible group. In addition, all countries have defined certain vulnerable population groups to be eligible for subsidization based on socio-demographic or socio-economic characteristics. The most frequently covered groups comprise older persons (Bolivia, Chile, Colombia, Dominican Republic, Uruguay), persons with disability (Bolivia, Chile, Costa Rica, Dominican Republic, Uruguay), (rural) self-employed workers (Costa Rica, Peru, Mexico, Colombia), and the unemployed (Dominican Republic, Peru, Uruguay) (see also Table 3). Due to their political situation and historical past, some countries have applied more context-specific eligibility criteria such as internally displaced persons and demobilized combatants (Colombia) or victims of state terrorism and human rights violations (Uruguay and Chile) (see Table 3, Column 2). In Peru, eligibility has recently been granted to all households located in specifically defined and particular poor and disadvantaged areas.

\section{Targeting and enrolment of eligible persons}

In order to identify individuals and households eligible for subsidization all countries use some form of targeting (see Table 3). Most countries studied use both direct and indirect targeting in a complementary way to identify eligible individuals. Direct targeting through (proxy) means testing by determining household income and/or assets are applied in six countries. Households are identified on the basis of surveys (in Chile, Colombia, Mexico, Peru) or via household visits (Costa Rica and Dominican Republic). Three countries (Colombia, the Dominican Republic, Peru) use social assistance identification systems that were originally set up for other social programmes to target individuals for subsidized health insurance. Indirect targeting is applied to include persons on the basis of sociodemographic (e.g., age, sex), socio-economic (occupation, employment status) or socio-geographic characteristics. These characteristics are easily observable and identifiable as well as correlated with vulnerability [19]. Another form of indirect targeting is to include beneficiaries of social assistance programs, namely beneficiaries of a conditional cash transfer program (Mexico), family allowances (Chile and Colombia), pension assistance schemes (Chile, Colombia and Dominican Republic), or social programs for demobilized combatants and internally displaced persons (Colombia).

Since 2010, Mexico has effectively extended eligibility in principle to all those outside the formal sector, abandoning its former direct targeting approach $[20,21]$. In Colombia, the central government had equally decided to shift to such a universalist approach, covering all outside the formal sector, however, resource constraints somewhat undermined these intentions [21].

Enrolment is mandatory in all countries except for Mexico and Uruguay. As to the actual enrolment process, both directly and indirectly targeted beneficiaries need to take active steps to get enrolled in all observed countries, except in Bolivia. Getting active implies that the potential beneficiaries need to be well informed about their entitlement to subsidization. In most countries, enrolment takes place at local or regional offices of the government organizations that are in charge of identifying eligible persons (Bolivia, Colombia, Costa Rica, Dominican Republic, Peru, Uruguay), or else at provider level, as in Chile and Mexico. To better reach eligible persons and make enrolment possible when attending health care services, 
Table 2 Country and Scheme Overview

\begin{tabular}{|c|c|c|c|c|c|c|}
\hline Country & $\begin{array}{l}\text { Name of subsidization scheme } \\
\text { (Year of introduction of the } \\
\text { subsidization scheme and } \\
\text { policy/law) }\end{array}$ & $\begin{array}{l}\text { Own account } \\
\text { workers (\% of } \\
\text { population) [51] }\end{array}$ & $\begin{array}{l}\text { GGHE as \% } \\
\text { of THE (1995) } \\
\text { [15] }\end{array}$ & $\begin{array}{l}\text { GGHE as \% of } \\
\text { THE (Year of } \\
\text { introduction) [15] }\end{array}$ & $\begin{array}{l}\text { GGHE as \% } \\
\text { of THE (2012) } \\
\text { [15] }\end{array}$ & $\begin{array}{l}\text { Social Security } \\
\text { Funds as \% of } \\
\text { GGHE 2012) [51] }\end{array}$ \\
\hline Bolivia & $\begin{array}{l}\text { "Mother and Child Universal } \\
\text { Insurance" (Seguro Universal } \\
\text { Materno Infantil, SUMI) } \\
\text { (2002), in existence already since } \\
1996 \text { as the Seguro Nacional de } \\
\text { Maternidad y Niñez, SNMN; } \\
\text { "Health Insurance for older persons" } \\
\text { (Seguro de Salud del Adulto Mayor, } \\
\text { SSPAM) (2006) These two insurance } \\
\text { type schemes were merged in } \\
\text { December } 2013 \text { into a new program } \\
\text { "the Integrated Health Service of } \\
\text { the Plurinational State" (Servicio } \\
\text { Integral de Salud del Estado } \\
\text { Plurinacional), that also covers people } \\
\text { with disabilities [28] }\end{array}$ & 33.2 & 57 & 63 (2002) & 72 & 37 \\
\hline Chile & $\begin{array}{l}\text { "National Health Fund" (Fondo } \\
\text { Nacional de la Salud, FONASA) (1979) } \\
\text { 2003: Plan de Acceso Universal de } \\
\text { Garantías Explícitas (AUGE) [28] - } \\
\text { this meant that an explicit } \\
\text { guaranteed benefit package } \\
\text { came into being. } \\
\text { Subsidization of vulnerable groups also through: } \\
\text { - Explicit Primary Health Care } \\
\text { Interventions Program } \\
\text { - Law of catastrophic insurance }\end{array}$ & $\mathrm{n} / \mathrm{a}$ & 48 & 38 (2004) & 49 & 9 \\
\hline Colombia & $\begin{array}{l}\text { "Subsidized Scheme" (Régimen } \\
\text { Subsidiado) (1993: "Mandatory } \\
\text { Health Plan" (Plan Obligatorio } \\
\text { de Salud) }\end{array}$ & 43.3 & 55 & - & 75 & 83 \\
\hline Costa Rica & $\begin{array}{l}\text { "Costa Rican Social Security Caisse" } \\
\text { (Caja Costarricense de Seguridad } \\
\text { Social, CCSS) } \\
\text { (1973: Ley } .^{\circ} \text { 5349, de Traspaso } \\
\text { de Hospitales) }\end{array}$ & 18.6 & 77 & - & 73 & 86 \\
\hline $\begin{array}{l}\text { Dominican } \\
\text { Republic }\end{array}$ & $\begin{array}{l}\text { "Subsidized Scheme" (Régimen } \\
\text { Subsidiado) (2001: Ley General } \\
\text { de Salud) }\end{array}$ & 33.2 & 22 & 34 (2001) & 67 & 47 \\
\hline Mexico & $\begin{array}{l}\text { Seguro Popular de Salud } \\
\text { (2004: Reglamento de la Ley } \\
\text { General de Salud en Materia } \\
\text { Protección Social en Salud) }\end{array}$ & $\mathrm{n} / \mathrm{a}$ & 42 & 44 (2004) & 52 & 56 \\
\hline Peru & $\begin{array}{l}\text { "Integrated Health Insurance" } \\
\text { (Seguro Integral de Salud) } \\
\text { (2009: Ley Marco de } \\
\text { Aseguramiento Universal } \\
\text { en Salud) }\end{array}$ & 33.6 & 54 & 57 (2001) & 61 & 35 \\
\hline Uruguay & $\begin{array}{l}\text { "National Integrated Health } \\
\text { System" (Sistema Nacional } \\
\text { Integrado de Salud) } \\
\text { (2007: Law No. 18,211) }\end{array}$ & 21.1 & 31 & $56(2007)$ & 71 & 60 \\
\hline
\end{tabular}

THE Total health expenditure, GGHE, General government health expenditure

Costa Rica and Peru have established these offices within the local health care facilities. In various cases public media campaigns serve to raise overall awareness for the respective subsidization schemes within the population [22].

\section{Financing sources}

Since the introduction of the subsidization scheme, the general government expenditure on health (GGHE) as a percentage of total health expenditure (THE) has risen in all countries (except Costa Rica where it remained at 


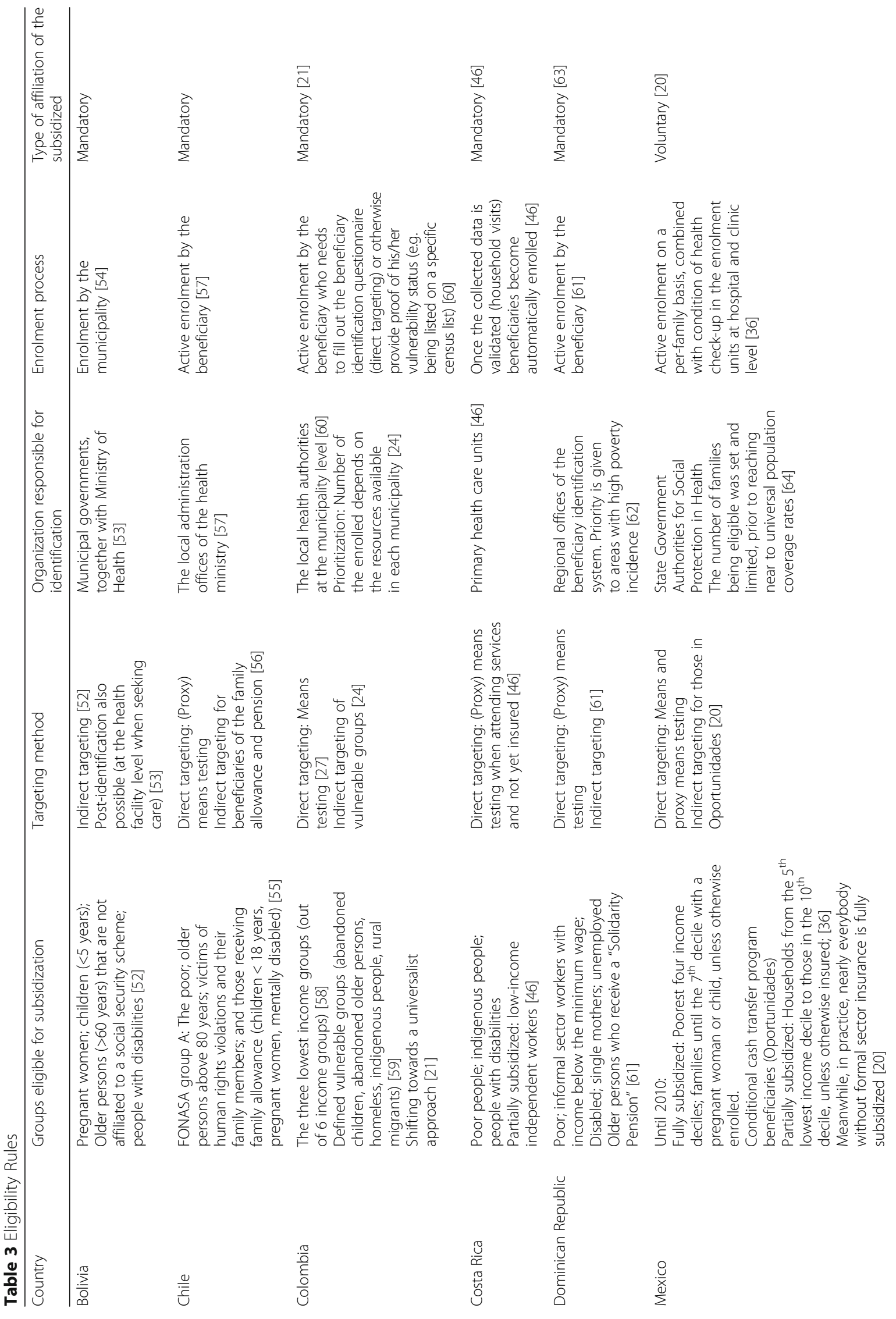




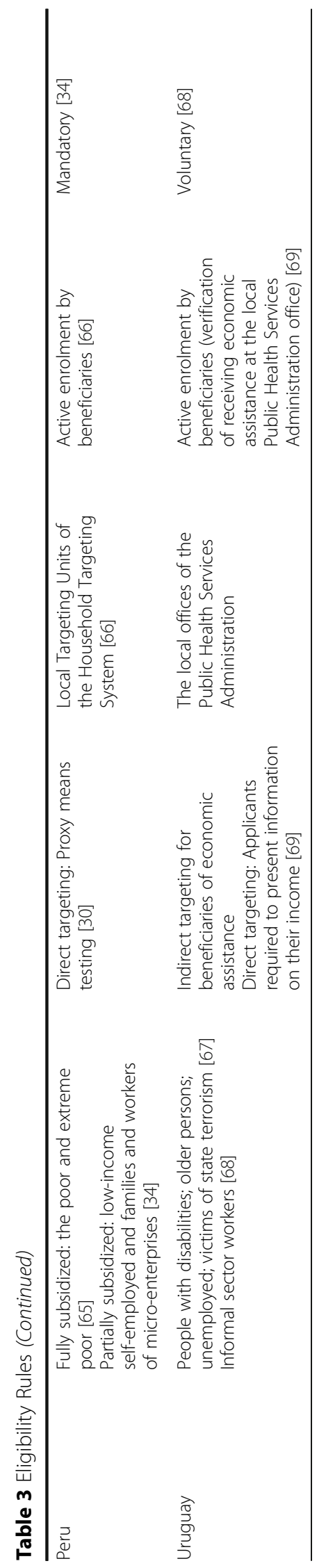


a high level), the increase ranging from 4 percentage points in Peru to $20 \%$ points and $33 \%$ points in Colombia (compared to 1995) and the Dominican Republic respectively (see Table 2). The scale of state budget subsidies is not insignificant, as revenue data from other regions suggest [11-14], but precise data is not available for these Latin American countries. Nonetheless, GGHE as a share of THE is still below 60\% in two countries (Chile and Mexico).

General government revenues are the main source for financing the subsidization schemes, with the exception of Colombia and Costa Rica (see Table 4, Column 2). Notably, in four countries (Bolivia, Chile, Colombia, Costa Rica), some sources of revenues are ear-marked for state budget transfers, these are predominantly "sin" taxes on tobacco, alcohol or gambling. Chile, on the other hand, earmarks its increased VAT, while Bolivia has an earmarked tax on hydrocarbons. Moreover, in Mexico, Peru, or Bolivia and Colombia, budget transfers come from state, regional or municipal revenues respectively. Notably, only in Peru is the subsidization scheme partly financed by donors, with $6 \%$ of its funds coming from donors and regional revenues [23]. Colombia is unique in using cross-subsidies as an important source of revenue for the subsidy scheme: $1.5 \%$ of total collections from the contributory regime are transferred to the subsidized scheme [24].

\section{Level of subsidization}

In all schemes, all population groups eligible for subsidization are fully subsidized and do not have to co-contribute, with a few exceptions only. These are largely poor people and the medically vulnerable. The exception applies to low-income informal sector and independent workers in Costa Rica, Peru and Mexico, who are only partially subsidized and who have to cocontribute (see Table 4, Column 5). The contribution rates for self-employed workers in Costa Rica's semicontributory regime range from 3.75 to $11.00 \%$ of income depending on the earnings. In Mexico, cocontributions for those households above the $5^{\text {th }}$ income decile (outside the formal sector) are supposed to rise with the income, but this rule has not been implemented: Only $1 \%$ of the enrolled households had contributed to Seguro Popular in the past, until it moved to a universalist approach. In Peru, the semi-contributory regime applies to about $5 \%$ of households, with contributions amounting to about two thirds of the average expenditure per insured.

\section{Calculation logic of the subsidy}

Countries use different approaches to determine the state budget transfer amount for the subsidized (see
Table 4, Column 3). The first approach is to define an overall budget as a lump sum transfer, which is negotiated annually and expanded depending on available funding. This approach is used in Chile, Costa Rica and Peru. A second way is to transfer a fixed share of the budget, which in the case of Bolivia is transferred from the national level to the municipalities, where it is pooled with the municipal health budget.

In a third group of countries, the subsidy transfer is based on a per capita amount, which is an estimate of what is needed to purchase the respective benefit package (individual-based calculation logic). This is in place in the Dominican Republic, Colombia and Uruguay. For the latter two, this per capita amount is risk adjusted. Finally, Mexico uses a mixed approach by combining the individual-based calculation logic for the fixed allocation per enrolled individual ("social contribution") and a riskadjusted federal "solidarity contribution". On average, the federal solidarity contribution amounts to $150 \%$ of the "social contribution" and depends on the number of enrolled individuals, health needs and the performance of health facilities.

\section{Pooling architecture}

The way resources are pooled determines how the costs of illness are shared across the population. Pooling of resources and health risks is found to take place in two ways: The subsidized are either covered by a separate scheme, or they are integrated and part of a national scheme (see Table 5). The latter option is found in three countries (Costa Rica, Chile and Uruguay), where a single health insurance fund at the national level includes and covers both the subsidized and the contributors, allowing for cross-subsidization. In Costa Rica, 50\% of revenues from contributions serve to finance coverage of the non-contributory groups [10]. In Chile, however, this potential for cross-subsidization is reduced to some extent, since usually younger, healthier and high income people decide to opt out from the public health insurance scheme and choose among a number of competing private insurers (Instituciones de Salud Previsional ISAPREs). In contrast, the other five countries (Bolivia, Dominican Republic, Peru, Mexico, Colombia) have established multiple pools, with a separate scheme for the subsidized and other schemes for formal sector employees. However, cross-subsidization from contributory scheme to the subsidized scheme exists in Colombia, where $1.5 \%$ of funds collected from payroll taxes $(12.5 \%$ of salaries) are transferred to the subsidized scheme. Notably, Colombia is the only country with a full-fledged model of managed competition applying to both the contributors' and subsidized scheme. The insured can choose from competing insurers/purchasing agencies (Health Promotion Entities for the Subsidized Regime) that are required 


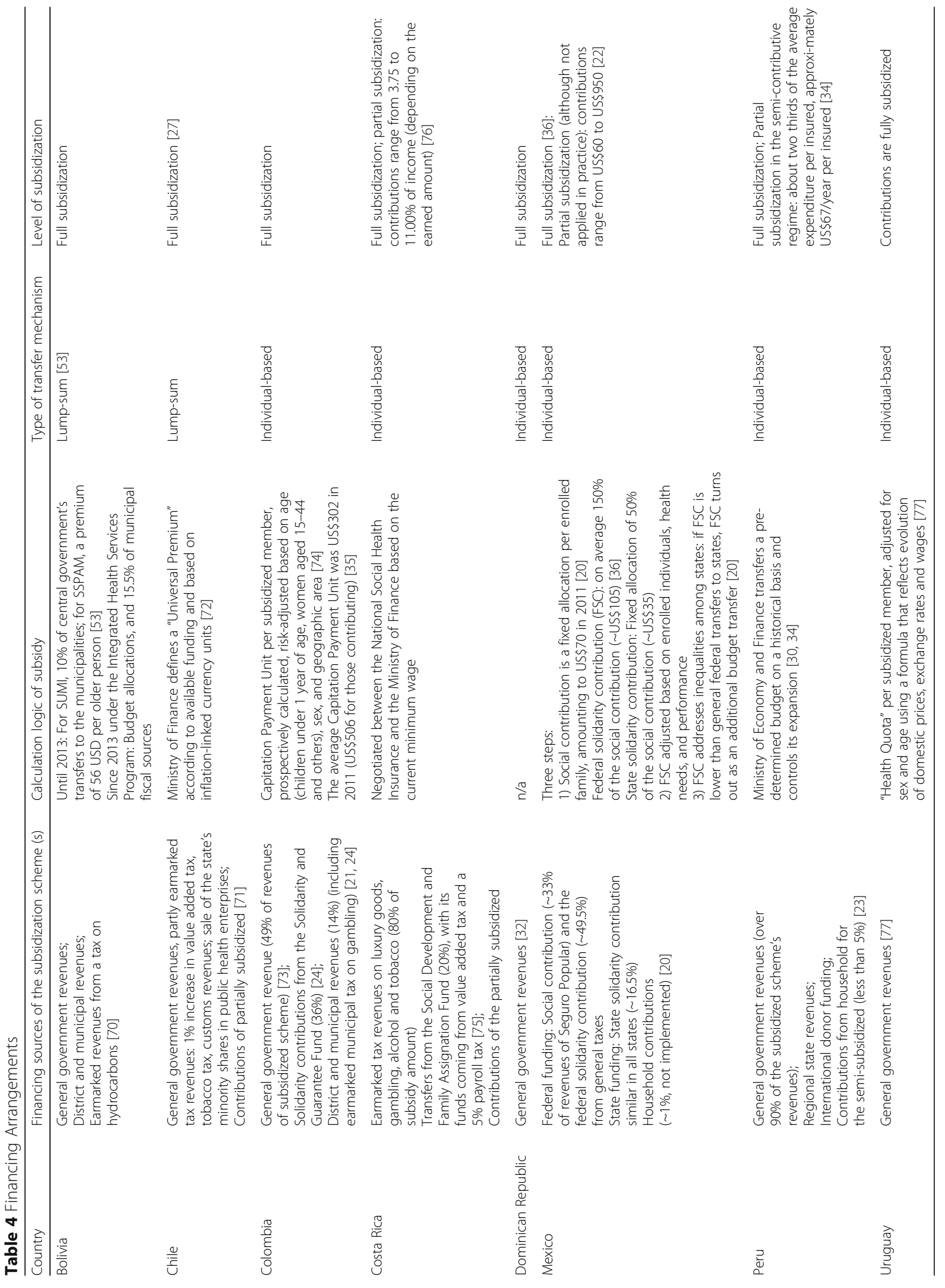


to ensure the provision of the Mandatory Benefit Package for the Subsidized Regime [25]. This multiple pool system is combined with risk-adjusted per capita allocation mechanism for the purpose of risk equalization across different schemes. Moreover, some countries have set up special funds for "catastrophic" diseases, i.e. illness events that may lead to very high, catastrophic expenditure. Finally, in several countries, fragmentation is further deepened through the existence of separate schemes for various public servant groups, such as the Armed Forces and the National Police [26].

Beyond fragmented, separate schemes, fragmentation also occurs along territorial lines. In Mexico, in Chile, and in Colombia and Bolivia, actual fund flows and pooling occurs at the state, regional and municipal level respectively. However, in Colombia, with the highest number of sub-pools (about 1,000), as well as in Mexico, central government funds are allocated on the basis of risk adjustment criteria to the sub-national pools. Mexico uses a federal solidarity contribution with the aim to adjust socio-economic inequalities across states with poorer states receiving more funding. In Colombia, prospective risk adjusted allocations for the sub-pools at the municipal level are based on age, sex and geographic area.

Last not least, the level of risk pooling is also determined by the type of membership. Mandatory affiliation is known to result in a more balanced risk composition and hence stronger redistributive capacity in contrast to voluntary affiliation. It is found that the subsidized are affiliated on a mandatory basis in all countries except for Mexico and Uruguay. However, in the Dominican Republic mandatory affiliation is actually not fully implemented. Moreover, as affiliation of formal sector employees is also mandatory in all countries, this further strengthens risk pooling in those countries with an integrated scheme. Yet, as Chile allows opting out to private health insurance schemes, this results in fragmentation and population groups with higher risks are concentrated in FONASA [27].

\section{Benefit package design: Scope of services and type of providers covered}

Purchasing is defined as the allocation of pooled funds to the health care service providers on behalf of the population for a defined benefit package. The definition of the range of services covered in the benefit package is decisive for the level of financial protection and access to care, as are the cost-sharing mechanisms. In general, over the recent decade, a real expansion of the benefits covered is notable $[9,28]$. Uruguay, which has introduced an "Integrated Health Care Plan" without specifically defining its contents, and Costa Rica have broad benefit packages, although rationing occurs through waiting lists for example. The other six countries have chosen to specify the explicitly guaranteed health services covered for all insured or for specific insured groups, e.g. through a health care plan or a list that defines by law which health conditions or clinical procedures are covered or not covered. The scope of these lists, however, varies (Table 6, Column 2). For Chile, Mexico and Colombia (since 2012), this is a relatively comprehensive package, covering in-patient, out-patient and specialized care as well as drugs. Compared thereto, the Dominican Republic and Peru have less comprehensive benefit packages for the subsidized, particularly in terms of in-patient care, specialized or high cost services. Moreover, four countries cover selected high-cost treatments through a separate catastrophic illnesses fund (Dominican Republic, Mexico, Peru, Uruguay). Over recent years, increases in available funding (in Chile, Mexico), but also, among other reasons, judicial trials (in Colombia, Costa Rica, Uruguay) have gradually expanded the range of benefit packages towards more specialized care interventions [29].

The covered benefit package for the subsidized is largely purchased from and delivered through government providers. However, in order to secure that services of the benefit package are actually provided, these can also be obtained from private providers in Colombia [21], Peru [30] and Chile [31]. Nonetheless, access to health services is unequal in that respect, since contributors have a more direct access to private providers, in particularly in the countries with separate schemes [28]. Last but not least, most countries have introduced portability of coverage within the whole country, such that beneficiaries have access to services beyond the area where they are registered.

\section{Cost-sharing mechanisms and rates}

In all the countries studied emergency care and some specific key (primary) health care services offered by public facilities of $\mathrm{MOH}$ can be accessed by everyone, regardless of insurance status, but co-payments are required [20, 21, $32,33]$. In contrast, for the covered benefit package the fully subsidized are completely exempt from any form of co-payments in all countries except in Colombia (Table 6, Column 3). In Colombia, the subsidized in the $3^{\text {rd }}$ and $4^{\text {th }}$ income groups (out of four categories and thus not belonging to the poorest), have to make co-payments of $10 \%$ up to a ceiling of a monthly' minimum wage.

Provider payment methods and purchasing arrangements Separate purchasing agencies are in place in all countries other than Mexico, Bolivia and Uruguay. But even when there is a separate purchasing agency, the separation of functions remains incomplete in countries where the purchaser channels funds to decentralised government 


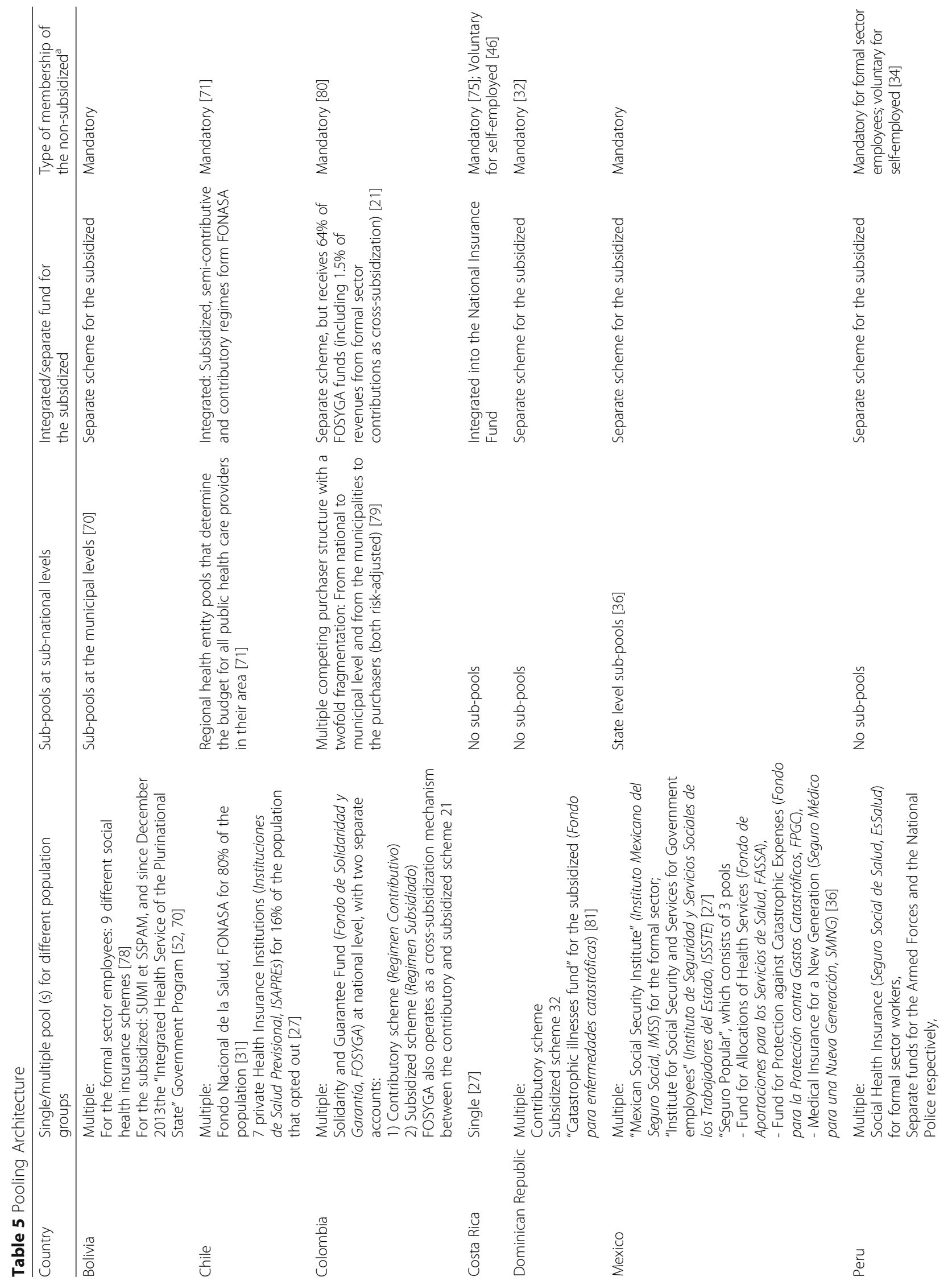




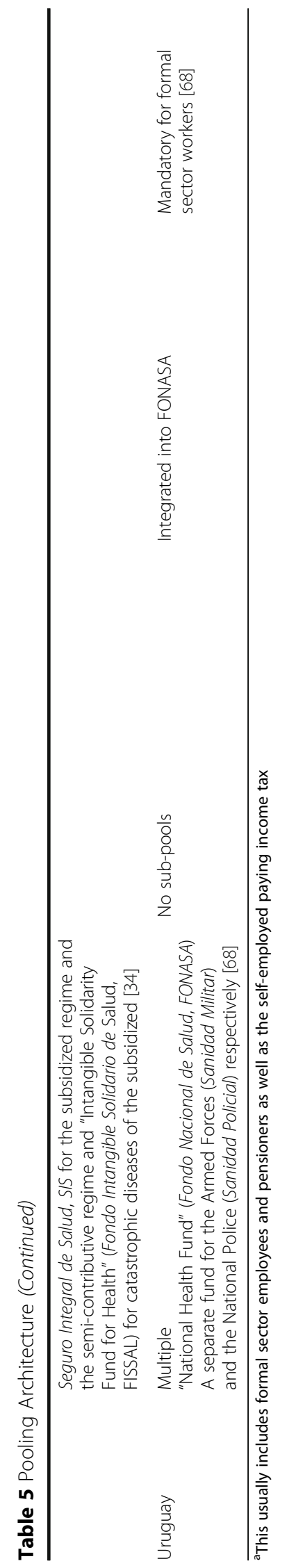




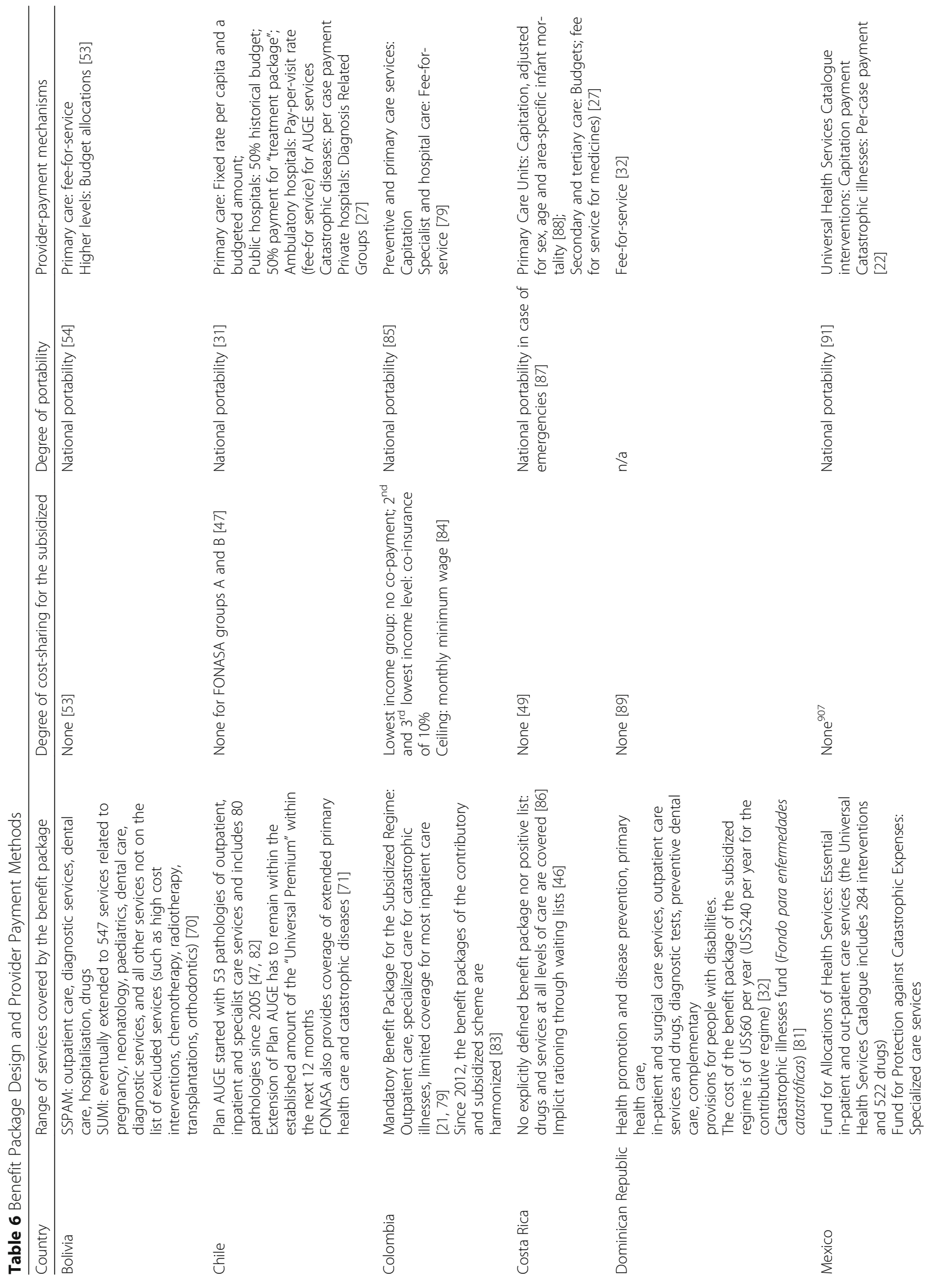




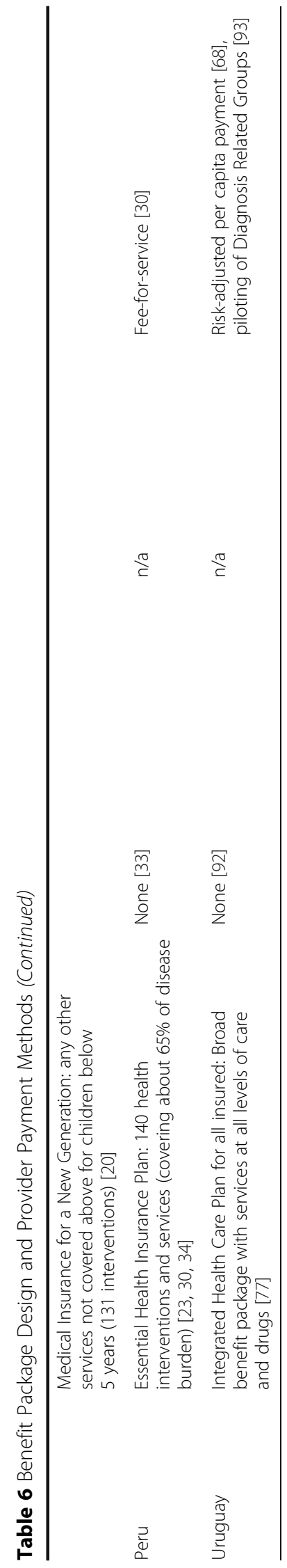


health authorities that pool them again with subnational budgets, such as in Chile. Beyond institutional design, there are also capacity challenges. For example, the Dominican Republic [32] and Peru [34] are reported to have experienced some problems to effectively contract providers. Potential advantages of a purchaserprovider split can thus not be pursued in its full potential, such as a move towards more strategic purchasing.

Related thereto, the types of provider payment methods in place have implications on provider behaviour and hence on access to care. As Table 6 shows, countries use a diversity of combinations of paying for both outpatient and inpatient care and there are efforts to move towards more strategic purchasing by using provider payment methods that set incentives for more efficient provider behaviour. For example, case payment is used in two and capitation is used in four countries respectively. Fee-for-service, nonetheless, remains very dominant. Most importantly, all countries studied use the same provider payment methods for the subsidized and those in the formal sector schemes, with the exception of Mexico. However, average per capita spending for the subsidized is found to be lower than for the contributors in a number of countries [32, 35].

\section{Progress on universal health coverage indicators Population coverage}

In view of the focus on subsidized health insurance type schemes here, population coverage is understood as the percentage of the population that is enrolled to a health insurance scheme. Total population coverage thereby indicates the comprehensiveness of the health insurance system in a country. It is important to note, though, that reported enrolment rates cannot be equated with effective access to health services. On the one hand, enrolment may not mean that people are already (or again) in possession of a (renewed) insurance card. Moreover, nonavailability of services and other supply side constraints such as staff shortages and quality concerns limit access.

As Table 7 shows, total enrollment rates are above 95\% in Uruguay, Chile, Colombia, and even higher in Costa Rica and Mexico. It is somewhat lower in Peru (72\% in 2012) and the Dominican Republic (69\% in 2016). Some of the countries studied have made substantial progress in enrolment rates within relatively short time. In Mexico in the early 2000s almost half of the population was without any type of insurance coverage. Since 2003 , more than $41 \%$ of the population got insured under the Seguro Popular [36]. In Peru, enrolment has increased from $37 \%$ in 2004 to $72 \%$ in 2012 $[33,34]$. The Dominican Republic has almost tripled the number of insured people within nine years; from $27 \%$ in 2007 to $55 \%$ in 2013 and $69 \%$ in 2016 (see Table 7, Column 2). Costa Rica and Colombia started much earlier on this road with impressive results as well. Chile and Uruguay have increased their already high insurance coverage rates from $89 \%$ in 2007 to $94 \%$ in 2012 and from $86 \%$ in 2007 to $95 \%$ in 2013 respectively. Hence over the last decade, all countries have made considerable progress in enhancing enrolment rates.

Looking specifically at the share of the subsidized as of total insured or total population gives an idea of the magnitude of the subsidization arrangement. In fact, there are large differences across countries (see Table 7, Columns 3 and 4). In Chile, Costa Rica and Uruguay, with coverage rates above $90 \%$, the share of the fully subsidized among the total insured population is only $20 \%, 11 \%$ and $5 \%$ respectively, since most of the population are contributors. This share is between $40-45 \%$ in Mexico, Bolivia and the Dominican Republic, yet also due to overall lower insurance coverage rates in the latter two countries. Colombia, with a high total insurance coverage rate, has the largest share of subsidized people within their insured populations (58\%). In Peru, on the other hand, the share of the subsidized among the insured is equally large (54\%), but the total enrolment rate is still lower at $72 \%$. The magnitude of the subsidization scheme is a function of the size of the formal sector, but also of the political commitment to define eligibility for subsidization more broadly.

Moreover, it is important to reveal whether and how effectively the subsidization schemes reach the target beneficiaries. Table 7 (Columns 5 and 6) also presents data related to targeting effectiveness: The inclusion error refers to the share of non-eligible individuals being enrolled in the subsidization scheme. The exclusion error refers to individuals that are in principle eligible but that are not enrolled. The high exclusion errors in Peru and in particular in the Dominican Republic are noteworthy and of concern. This may relate to the primarily direct targeting approach applied in those two countries. However, the exclusion error also needs to be seen in relation to the size of the eligible population. For example, in Costa Rica with $12 \%$ being eligible for subsidization, the $10 \%$ exclusion error affects $1 \%$ of the total population.

With respect to the inclusion error, on the other hand, more recent data is only available for Colombia and Peru, however, wrong inclusion is also reported for other countries. The share of non-eligible persons among those being subsidized had been high in Mexico and ranged from $54 \%$ to $60 \%$ in the years after the introduction of the Seguro Popular [37, 38]. One reason related to the way Seguro Popular is financed. There is no incentive for the State Government Authorities for Social Protection in Health to assess household income to determine household contributions to be collected upon enrolment. Instead, federal 
Table 7 Insurance Enrolment Rates

\begin{tabular}{|c|c|c|c|c|c|}
\hline Country & $\begin{array}{l}\text { Insurance Enrolment Rates of } \\
\text { Total Population (in \%) }\end{array}$ & $\begin{array}{l}\text { Share of subsidized within } \\
\text { total population (in \%) }\end{array}$ & $\begin{array}{l}\text { Share of subsidized within total } \\
\text { insured population (in \%) }\end{array}$ & Exclusion error & Inclusion error \\
\hline Bolivia & 43\% (2008) [94] & $12 \%$ (2008) [94] & $\begin{array}{l}28 \%(2008) \\
42 \%(2012)\end{array}$ & $\mathrm{n} / \mathrm{a}$ & $n / a$ \\
\hline Chile & $\begin{array}{l}89 \%(2004) ; \\
94 \%(2012)[95]\end{array}$ & 20\% (2012) [95] & 19\% (2012) [95] & $\mathrm{n} / \mathrm{a}$ & $\mathrm{n} / \mathrm{a}$ \\
\hline Colombia & $\begin{array}{l}89 \%(2008)[79] ; \\
96 \%(2010)[21]\end{array}$ & 53\% (2014) [79] & 58\% (2014) [79] & $2 \%(2013)[21]$ & $16 \%$ (2013) [21] \\
\hline Costa Rica & $\begin{array}{l}\text { 87\% (2003); } \\
98 \%(2014)[27]\end{array}$ & $11 \%(2014)$ & $\begin{array}{l}11 \%(2010)[75] \\
10.6 \%(2014)\end{array}$ & 10\% (2010) [46] & $\mathrm{n} / \mathrm{a}$ \\
\hline Dominican Republic & $\begin{array}{l}40 \%(2009)[32] \\
55 \%(2013)[96] \\
69 \%(2016)[97]\end{array}$ & 25\% (2013) [96] & 46.\% (2013) [96] & 68\% (2009) [32] & $\mathrm{n} / \mathrm{a}$ \\
\hline Mexico & $\begin{array}{l}57 \%(2003) ; \\
98 \%(2012)[36]\end{array}$ & 44\% (2012) [36] & $44 \%(2012)$ & 10\% (2009) [22] & $\mathrm{n} / \mathrm{a}$ \\
\hline Peru & $\begin{array}{l}\text { 64\% (2010); } \\
72 \%(2012)[33]\end{array}$ & 39\% (2012) [33] & 54\% (2012) [33] & 16\% (2013) [30] & $12 \%(2003)$ \\
\hline Uruguay & $\begin{array}{l}\text { 86\% (2007); } \\
95 \%(2013)[77]\end{array}$ & $5 \%$ (2013) [77] & $5 \%(2013)$ & $\mathrm{n} / \mathrm{a}$ & $\mathrm{n} / \mathrm{a}$ \\
\hline
\end{tabular}

transfers to the states depend on the number of enrolled individuals and assessing income and collecting contributions from them would reduce their willingness to enrol [20]. As a result, a high enrolment rate was achieved at the expense of a high inclusion error that implied large amounts of public funds going to households not in need for it [37].

\section{Financial protection}

Global evidence has shown that there is a strong correlation between out-of-pocket expenditure (OOP) as a share of total health expenditure (THE) and the share of households experiencing financial hardship [39]. Thus, a starting point is to look at trends in OOP as a share of THE. Financial protection, specifically, can be measured in two complementary ways. One is to measure the incidence of catastrophic expenditure. This occurs when a household's total OOP equal or exceed $40 \%$ of the household's non-subsistence spending, i.e. their capacity to pay, as per the WHO definition [40]. Different (lower) thresholds of determining catastrophic expenditure have also been proposed in the literature and are being used (and reported here). The second measure is impoverishing health expenditure that occurs when OOP pushes a household below the poverty line or even deeper into poverty [39].

Across the Latin American countries studied here, three countries (Peru, Chile, Mexico) have a relatively higher share of OOP expenditure (between 29\% and $44 \%$ in 2014) compared to the other five countries, where OOP expenditure as of THE ranges between 15\% and 25\% in 2014. However, other than in Costa Rica and
Uruguay with slight increases, OOP has been decreasing [15]. Data in Table 8 (Column 3) also confirms that countries with a higher OOP share tend to have a relatively higher incidence of catastrophic health expenditure. In fact, the lowest incidence of catastrophic health expenditure (at a $40 \%$ threshold level) is found in Costa Rica (0.4\%), whereas it is considerably higher in Chile $(6.4 \%)$ and in the Dominican Republic (9.8\%, however at a $30 \%$ threshold), despite the latter's moderate OOP level of $21 \%$. Moreover, disaggregated data reveals that a high percentage of households from the lowest two income quintiles faces catastrophic health expenditure at a 25\% threshold in Chile and Colombia (15 and 10\% respectively), while this percentage is the lowest in Costa Rica (1\%).

\section{Access to health care services}

Enrolment rates and financial protection indicators do not reveal whether people actually have effective access to needed health services, i.e. the ability to receive health services they need implying the availability, affordability and acceptability of services, or whether they forego seeking care [41]. This is difficult to measure directly, as need cannot be easily captured for all health services. Utilization rates for inpatient and outpatient care are therefore used as proxy indicators. Comparing utilization rates before and after the introduction of the subsidization scheme and between the insured and uninsured over time, or if that data is not available, across income quintiles, may thereby reveal improvements or prevailing inequities in access to care.

Data on health service utilization rates before and after the introduction of the subsidization schemes were only 


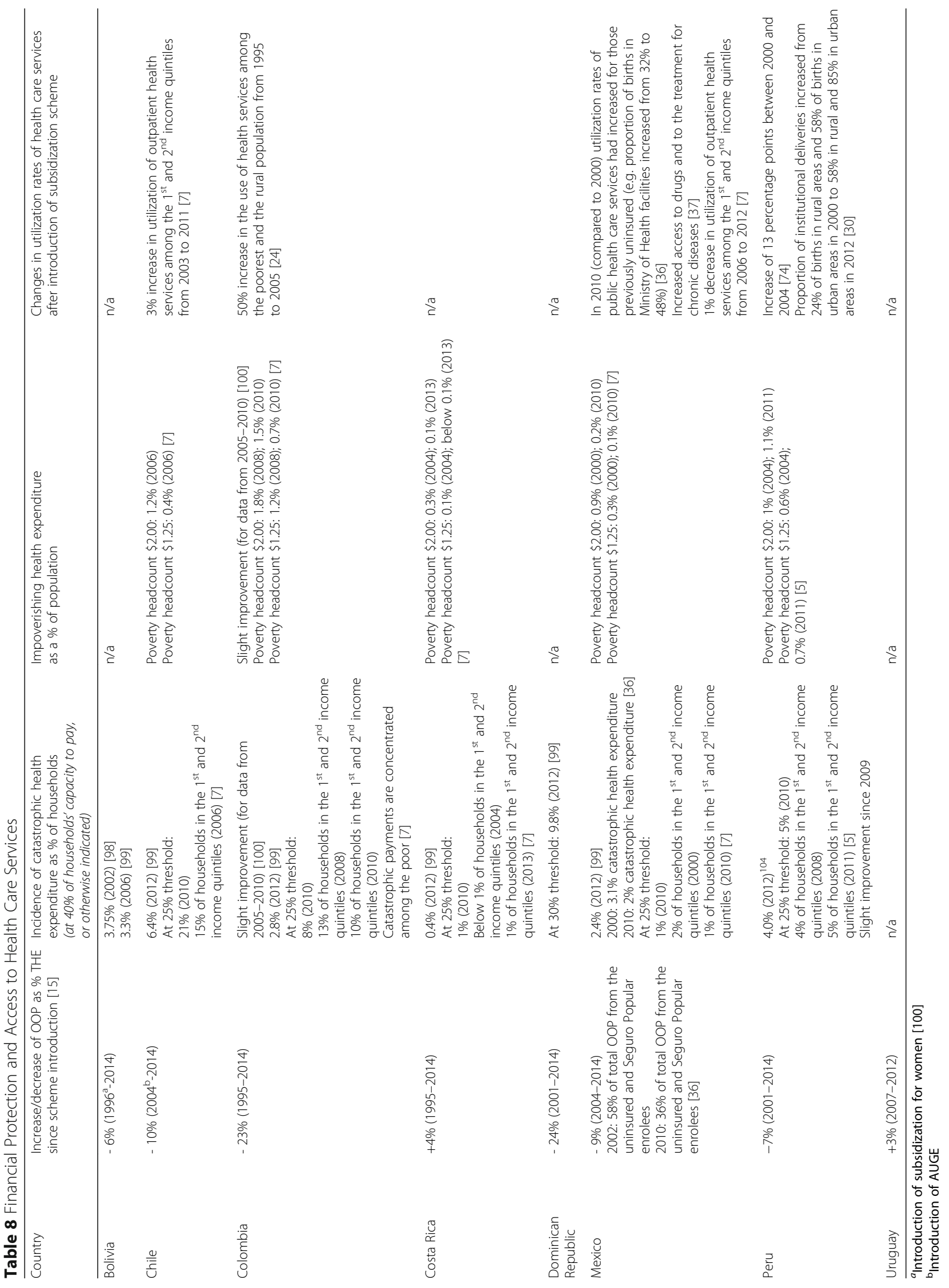


available for four countries. Although utilization rates remained lower than the ones of contributors, access to health care services has improved for the poorest income quintiles in all these countries (see Table 8, Column 5). This increase has been very high in Colombia, where in comparison to the remaining uninsured, a $50 \%$ increase in the use of health services among the subsidized urban poor and the rural population could be observed over the period of 1995 to 2005.

\section{Discussion}

\section{Effects of eligibility criteria and targeting approach on population coverage}

This section explores the plausible contribution of institutional design features relating to eligibility and enrolment rules on UHC progress and also highlights particular challenges. The way eligibility for subsidization is defined together with the specific targeting method seem to be decisive for insurance coverage rates of the subsidized groups.

Eligibility criteria and what is considered as vulnerable vary somewhat across the countries, although most countries pursue several definition logics to capture the most vulnerable population groups, which partly overlap. All countries except Bolivia originally put a strong focus on the poor, identifying them on the basis of assessing their means and income. Another focus is on sociodemographically defined groups (children, older persons, pregnant women or mothers). A third eligibility logic is to include social security or social assistance recipients, e.g., the unemployed, disabled and family allowance beneficiaries, such as in Uruguay, Mexico, Dominican Republic and Chile.

However, there remain critical coverage gaps of some specific economically or medically vulnerable population groups. It is found that illegal immigrants and people without documents are not explicitly mentioned as being eligible for subsidization in all countries studied, and hence they remain excluded [42] as are indigenous people (in Peru for example) [43] and internally displaced persons [44] in some countries and areas. Another group are the officially unemployed [45]. Also, many of Peru's uninsured are not poor but low-income and would be eligible for the semi-contributive regime. Still, enrolment of these persons is difficult to implement and as in other countries across the globe, partial subsidization has not considerably increased population coverage. Limited resources also determine the definition of eligibility criteria. For example, in Bolivia, due to resource constraints, eligibility had been restricted to pregnant women, children and older persons, until coverage was slightly expanded to include people with disabilities in 2013 under the new scheme.

As to the effect of different targeting approaches, evidence suggests that indirect targeting may be more prone to inclusion errors. Also, it appears that direct targeting is one contributing factor for higher exclusion errors, as exampled by Peru and the Dominican Republic (with a primarily direct targeting approach) as well as Mexico in earlier years. But the exclusion error can also be due to cumbersome enrolment procedures, as found in Costa Rica with a $10 \%$ exclusion error relating to $12 \%$ of the population being eligible for subsidization [46]. The near to universalist approach that Mexico applies since 2010 in practice results in close to $100 \%$ population coverage rates. Yet, this is realized at the cost of an inclusion error of people that should be covered by the formal sector insurance schemes.

Due to limited evidence, it remains unclear to what extent the design feature of mandatory membership enhances enrolment rates and whether active enrolment by the authorities to facilitate enrolment is decisive even under mandatory affiliation. Moreover, the chosen targeting approach does not always coincide with fiscal reality and resource availability. This was the case in Colombia for example, where some municipalities were not able to mobilize sufficient resources for their per capita budget transfer to subsidize the enrolment of all eligible people outside the formal sector [21, 26]. However, generally speaking, if municipal funding is required to enrol eligible individuals, the incentive to enrol may not be as strong. In Colombia, as a result, certain vulnerable groups were prioritized over others [24]. In recent years, however, this challenge has been overcome. Likewise, in the Dominican Republic and Peru, resource constraints and slow implementation of their targeting approaches (also applied in other social assistance/protection programmes) equally explain the high exclusion error thus preventing the actual population coverage potential as per their eligibility rules [30, 32].

\section{Effects of the pooling architecture on equity in access}

Some variation is found among countries with respect to critical pooling design aspects, namely scheme integration versus scheme separation as well as mandatory versus voluntary membership. This determines the size and composition of the risk pool and thus the level of fragmentation as well as the scope for cross-subsidization within the system. Among the three countries with an integrated pool, Costa Rica stands out with a high degree of cross-subsidization from the contributors to noncontributors. It is also notable that for the five countries with separate schemes, benefit packages differ despite harmonization efforts in some cases, and in fact, in these countries, the subsidized have access to a smaller benefit package than the contributors.

Only one of these countries (Colombia) has established a direct cross-subsidy mechanism across different schemes in addition to risk-adjusted per capita 
allocations for the subsidized scheme. This, however, did not overcome inequalities in access to services and thus perpetuates differences in financial protection of those in the subsidized scheme versus those in the contributory scheme. Hence, the coexistence of multiple schemes in which different socio-economic groups are covered by different funding pools, maintains or even increases inequalities in access and financial protection in the countries with separated schemes.

Mandatory coverage increases risk pooling, even in the four countries with separate schemes. When coupled with an integrated risk pool, solidarity in financing and the scope for cross-subsidization is larger, such as in Uruguay and Costa Rica. With its opting out option, Chile (with an integrated scheme) is the only country with substitutive private health insurance, thus limiting overall solidary and equity in financing and access. Moreover, ISAPREs members can switch back to FONASA, especially above a certain age or when suffering from severe illness, when their premiums and co-payments increase. As such, FONASA is burdened with the high-risk members, whereas ISAPREs engages in risks-selection to enrol low-risk members [47]. Reform discussions are underway on how to reform and unify the two sub-systems of FONASA and ISAPREs.

Countries with sub-pools at sub-national levels are particularly prone to the problem of unequal access to health services when there are different socio-economic conditions and disease burden across sub-national units. Therefore, Colombia and Mexico have developed risk adjustment mechanisms. In Mexico, this new formula of resource allocation from the federal level has improved the funding situation in poorer states such as Chiapas and Oaxaca [37]. However, the impact the risk adjustment mechanism actually had on the financing situation in poorer states should not be overestimated since more funding was available in all states after the introduction of the Seguro Popular in 2003 [37]. The complexity and difficulty of balancing risks across sub-pools was also experienced in Colombia, where the indicators used did not adequately predict the population's health needs and demand for health services in each area. [21] New and more sophisticated risk adjustment techniques are being considered [21].

\section{Effects of benefit package design on financial protection and access}

The benefit package design including its co-payment mechanisms and rates as well as benefit ceilings for the subsidized affect the degree of financial protection and utilization rates. One important commonality across countries is that there are no co-payments for the subsidized, except in Colombia. In combination with expanded benefit packages, this could have contributed to the reduction in OOP in most countries. Likewise, this may explain increased utilisation rates noted in all countries with available data.

Another important feature are the specific and explicit lists of services covered in the benefit package. Some argue that these specific lists are potentially more effective, equitable and efficient than implicit rationing [48]. However, the comparatively larger scope of the benefit package in Costa Rica and Uruguay can be considered to have had an important impact on the relatively higher levels of financial protection. For example, in Costa Rica OOP mainly occurs when attending outpatient services such as dentist consultations or when paying for certain medicaments. In contrast, OOP on in-patient care is minimal [49], and its catastrophic health expenditure is the lowest among all the countries studied. In view of the relatively higher OOP share in Mexico, yet its relatively lower incidence of catastrophic expenditure, Seguro Popular seems to be able to provide financial protection for the subsidized. This suggests that even if overall OOP may not decline rapidly with high coverage because of many factors - one being that families were under-spending on health before UHC - the risk of catastrophic or impoverishing health expenditures is substantially reduced. Again, the selection of services being covered including those covered by the Catastrophic Expenses Protection Fund may explain this phenomenon.

However, except for Colombia since 2012, the scope of the benefit package in countries with separate schemes is not equal to the one for those enrolled in the contributory scheme and has resulted in lower capitation payments for the subsidized [7]. For example, average capitation payments differ quite significantly in the Dominican Republic (four times higher for contributors in 2010 [32]) and Peru [34]. Likewise, in Colombia in 2011, US\$ 506 was spent per contributor compared to US\$ 302 per subsidized [35]. In 2012, the government passed new regulations that aimed at all citizens having the same benefit package regardless of their health insurance coverage arrangement. Moreover, even when benefit packages are harmonized and come along with similar payment rates, effective access may still remain unequal due to service quality problems and supply side constraints that may persist especially in remote and poor areas where the subsidized live [21, 32].

\section{Effects of provider payment methods and purchasing arrangements on access}

While all countries studied use the same provider payment methods for the subsidized and those in the formal sector schemes, with the exception of Mexico, payment rates have differed and average per capita spending for 
the subsidized was found to be lower than for the contributors in a number of countries. This may be due lower utilisation rates of the subsidized, or else due to hidden incentives for cream skimming, i.e. preferring some patients from one population group, which in turn can lead to the under-provision of services to financially less attractive subsidized patients. More data is needed to assess this further.

Likewise, evidence on purchasing arrangements is insufficient to determine whether the introduction of a purchaser-provider split as well as contracting of providers in all countries have increased service delivery, efficiency and equity for the subsidized. Colombia is the only country studied that manages competition among purchasers, but this has not right away resulted in more choices and competition among providers. Accordingly, Frenk (2014) suggests that countries need to further strengthen the separation of functions [17].

In sum, the lack of data on UHC progress is a limitation to assessing the effect of critical institutional design features, and there is thus need for robust and rigorous impact studies. Future research should generate more evidence on the implementation process as well as the impacts of the schemes on UHC progress, differentiated along population groups, income quintiles as well as insured versus uninsured and the contributors versus the subsidized. This is the basis to explore further options of improving coverage and also provide lessons to other countries across the globe that plan to introduce subsidization schemes.

\section{Conclusion}

This paper explored the patterns of institutional design aspects of subsidization arrangements using state budget transfers with a focus on population groups outside formal sector employment and especially vulnerable population groups. Notably, the analysis revealed numerous commonalities but also differences across countries. A number of policy lessons can be derived from this analysis.

First of all, in all countries, the poor are fully subsidized and do not have to pay partial contributions. This is analogous to the design features that were revealed in all the other regional studies with the same research question [11-14]. The main challenge here is to ensure that the amount of transfers is sufficient and allows for sustainability of the health insurance type scheme in the long run. An important institutional design feature is the choice of the targeting method. Where a universalist approach of covering all those outside formal sector work is not (yet) feasible given the fiscal situation, a combination of both direct and indirect targeting, including socio-demographic, socio-economic and/or socio-geographic criteria, is conducive to increase enrolment rates. This design pattern is also found in Asia and Africa primarily. Equally critical is to make affiliation mandatory, which all countries except two did. Again this is similar to the design pattern found in the other regions. Other important features are the specific and explicit lists of health services covered in the benefit package and exemption of the subsidized from co-payments. One key lesson is that this has to go along with increased state budget revenues the amount of which needs to be adapted to both the (increasing) number of affiliated persons, particularly when participation is mandatory, and to the average costs of the benefit package.

With regards to pooling, countries that established integrated schemes along with mandatory coverage reduced fragmentation and have a better chance to improve equity in access and financial protection. Thus, in the medium and long term, the most desirable way for countries with separated schemes to improve equity is to merge separate schemes into one integrated health financing system without opt-out options for the betteroff. In the short term, the aim could be to work towards a harmonized benefit package, at least with respect to the range of services of covered and more equal per capita spending. Yet, although a prerequisite for access, it is clear that legally granted coverage and comprehensive benefit packages on paper are not enough in view of existing quality differences between rural and urban areas and wealthy and poorer communities. There is urgent need to have sufficient funding reaching the facility, but also to allocate resources more equally within a country. Access to good quality health services can only become a reality if shortages in human resources, infrastructure and supplies are also addressed. Moreover, it is important that people are well informed about their entitlements, particularly in terms of their eligibility status for subsidization and the scope of the respective benefit package.

Despite the considerable progress achieved through the subsidization arrangements that made a difference to thousands of people, there remain concerns as to inequity in access and financial protection across income quintiles and population groups even in countries with integrated schemes. Moreover, certain population groups remain excluded as they are not eligible for subsidization, in particular near- or non-poor informal workers. There is need to expand eligibility criteria to cover the hard to reach groups as well.

In addition to favourable institutional design, expansion of population coverage to so far non-covered population groups as well as extension of the health services covered is also enhanced by economic growth that opens the necessary fiscal space for subsidization, coupled with political will. Countries with limited resources can expand coverage in a progressive way.

Overall, this analysis suggests that state budget transfers to health insurance type arrangements have been 
one way to expand coverage of vulnerable groups and those outside formal sector work in the studied countries. As in Africa and Asia, this financing arrangement is gaining momentum across the Latin American region and reflects the move towards a human rights based approach to health in which entitlements are no longer linked to members' direct contributions.

\section{Abbreviations}

AUGE: Plan de acceso universal de garantias explicitas (Chile); FONASA: Fondo nacional de la salud (Chile); GGHE: General government health expenditure; ILO: International labour organization; ISAPREs: Instituciones de salud previsional (Chile); MOH: Ministry of health; OECD: Organization for economic co-operation development; OOP: Out-of-pocket expenditure; PAHO: Pan America health organization; SHI: Social health insurance; THE: Total health expenditure; UHC: Universal health coverage; WHO: World health organization

\section{Acknowledgements}

We thank lleana Vilcu for her valuable support and research assistance, particularly on data analysis. We express our gratitude to Ariostus Matus for his inputs to the literature search and valuable comments, in particular on Mexico. Last not least, we also thank and gratefully acknowledge very helpful comments from Claudia Pescetto, Cristian Morales and Fabio Durán Valverde. The authors are responsible for all remaining errors.

\section{Funding}

Financial support to WHO was provided by the UK Department for International Development (DFID) under the Program for Improving Countries' Health Financing Systems to Accelerate Progress towards Universal Health Coverage, as well as from the EU-Luxembourg-WHO UHC Partnership program. At the time of the research and manuscript drafting, Thorsten Behrendt was a volunteer with the HGF Department - his fellowship was funded by the Carlo Schmid Program.

\section{Availability of data and materials}

All data supporting the findings of this study are available within the article and references are provided. Published articles were found via Scopus, Science Direct, PubMed and JSTOR as well as Scielo and CLASE for Spanish publications. All other material was accessed from publicly available webpages, as indicated in the reference section.

\section{Authors' contribution}

IM conceived the study and its design. TB undertook the literature review. IM and TB undertook the analysis and interpretation of data and drafted the manuscript. All authors have read and approved the final manuscript.

\section{Authors' information}

IM is a health systems development and health financing specialist in the Department of Health Systems Governance and Financing at the World Health Organization in Geneva. At the time of writing, TB was a volunteer within the same department and now works as an advisor for the social health protection network Providing for Health (P4H) at the Deutsche Gesellschaft für Internationale Zusammenarbeit (GIZ) in Bonn, Germany.

\section{Competing interests}

The authors declare they have no competing interests.

\section{Consent for publication}

Not applicable.

\section{Ethics approval and consent to participate}

Not applicable.

\section{Author details}

'Department of Health Systems Governance and Financing, World Health Organization, Avenue Appia, 1211 Geneva, Switzerland. ${ }^{2}$ Deutsche Gesellschaft für Internationale Zusammenarbeit (GIZ), Friedrich-Ebert-Allee 36, 53113 Bonn, Germany.
Received: 10 August 2016 Accepted: 11 January 2017

Published online: 16 February 2017

\section{References}

1. Bitran R. Universal Health Coverage and the Challenge of Informal Employment: Lessons from Developing Countries [Health, Nutrition, and Population (HNP) Discussion Paper]. Washington DC: World Bank Group: 2014. [cited 2014 Dec 28]. Available from: URL:http://documents.worldbank. org/curated/en/2014/01/19491214/universal-health-coverage-challengeinformal-employment-lessons-developing-countries.

2. Kutzin J, Shishkin S, Brydnova L, Schneider P, Hrobon P. Reforms in the pooling of funds. In: Kutzin J, Cashin C, Jakab M, editors. Implementing health financing reform: Lessons from countries in transition, vol. 21. Brussels: European Observatory on Health Systems and Policies; 2010. p. 119-54.

3. Carrin G, James C. Social Health Insurance: Key Factors Affecting the Transition Towards Universal Coverage. Int Soc Secur Rev. 2005;58(1):45-64.

4. Savedoff WD. Is there a case for social insurance? Health Policy Plan. 2004;19(3):183-4.

5. World Health Organization. The world health report - Health systems financing: The path to universal coverage. 2010. [cited 2013 Jul 8]. Available from: URL:http://www.who.int/whr/2010/en/index.html.

6. Pan American Health Organization. Strategy for Universal Access to Health and Universal Health Coverage [53rd Directing Council, 66th Session of the Regional Committee of WHO for the Americas, Washington D.C., USA. 2014. [cited 2014 Dec 28]. Available from: URL:http://www.paho.org/hq/index. php?option=com_docman\&task=doc_download\&gid=27312\&ltemid= 270\&lang=fr.

7. Dmytraczenko T, Almeida G, editors. Toward Universal Health Coverage and Equity in Latin America and the Caribbean: Evidence from Selected Countries: The World Bank; 2015.

8. Meng Q, Yuan B, Jia L, Wang J, Yu B, Gao J, et al. Expanding health insurance coverage in vulnerable groups: a systematic review of options. Health Policy Plan. 2011;26(2):93-104.

9. Atun R, de Andrade, Luiz Odorico Monteiro, Almeida G, Cotlear D, Dmytraczenko T, Frenz P, Garcia P, Gómez-Dantés O, Knaul FM, Muntaner C, de Paula, Juliana Braga, Rígoli F, Serrate PC, Wagstaff A. Health-System Reform and Universal Health Coverage in Latin America [Universal Health Coverage in Latin America 1]: The Lancet; 2014 [cited 2014 Dec 28]. Available from: URL:http://www.thelancet.com/journals/lancet/article/ PIIS0140-6736\%2814\%2961646-9/abstract.

10. Titelman $\mathrm{D}$, Cetrángolo $\mathrm{O}$, Acosta OL. Universal Health Coverage in Latin American Countries: How to Improve Solidarity-based Schemes. The Lancet 2014.

11. Vilcu I, Mathauer I. State budget transfers to health insurance funds for universal health coverage: Institutional design patterns and challenges of covering those outside the formal sector in Eastern European high-income countries. International Journal for Equity in Health 2016; 15(7).

12. Mathauer I, Theisling M, Mathivet B, Vilcu I. State budget transfers to health insurance funds: extending universal health coverage in low- and middleincome countries of the WHO European Region: Institutional design patterns and challenges in low-and middle-income countries of the WHO European Region. Int J Equity Health. 2016;15(1):57.

13. Vilcu I, Probst L, Bayarsaikhan D, Mathauer I. Subsidized Health Insurance Coverage of People in the Informal Sector and Vulnerable Population Groups: Institutional Design Trends in Asia. Int J Equity Health. 2016;15:165.

14. Mathauer I, et al. Budget transfers to health insurance: Design features and challenges in Africa [HGF Draft Discussion Paper]: World Health Organization. 2016.

15. World Health Organization. Global Health Expenditure Database: Table of key indicators for all the Member States. 2016. Available from: URL:http://apps. who.int/nha/database/Select/Indicators/en.

16. Kutzin J. A descriptive framework for country-level analysis of health care financing arrangements. Health Policy Plan. 2001;56(3):171-204.

17. Frenk J. Leading the Way towards Universal Health Coverage: A Call to Action [Universal Health Coverage in Latin America 4]: The Lancet; 2014 [cited 2014 Dec 28]. Available from: URL:http://www.thelancet.com/journals/ lancet/article/PIIS0140-6736\%2814\%2961467-7/abstract.

18. The World Bank. New Country Classifications; 2013 [cited 2014 Jun 8]. Available from: URL:http://data.worldbank.org/news/new-country-classifications.

19. Gwatkin D. Are Free Government Health Services The Best Way to Reach the Poor?: The World Bank; 2004 [cited 2014 Jun 7]. Available from: URL: http://siteresources.worldbank.org/HEALTHNUTRITIONANDPOPULATION/ Resources/281627-1095698140167/Chapter2Final.pdf. 
20. Bonilla-Chacín ME, Aguilera N. The Mexican Social Protection System in Health [Universal Health Coverage Studies Series (UNICO) No. 14]: The World Bank; 2013 [cited 2014 Feb 25]. Available from: URL:http://siteresources. worldbank.org/HEALTHNUTRITIONANDPOPULATION/Images/MexicanSocial ProtectionSysteminHealth.pdf.

21. Montenegro-Torres F, Acevedo OB. Colombia Case Study: The Subsidized Regime of Colombia's National Health Insurance System [Universal Health Coverage Studies Series (UNICO) No. 15]: The World Bank; 2013 [cited 2014 Feb 25]. Available from: URL:http://www.worldbank.org/en/topic/health/ publication/universal-health-coverage-study-series.

22. Joint Learning Network for Universal Health Coverage. Mexico: Seguro Popular; 2014 [cited 2014 Mar 3]. Available from: URL:http://programs. jointlearningnetwork.org/content/seguro-popular.

23. Alcalde-Rabanal JE, Lazo-González O, Nigenda G. Sistema de salud de Perú. Salud Publica Mex. 2011;53(2):S243-54.

24. Torrenegra-Cabrera EC. The Subsidized Health-care Scheme in the Social Protection System. In: International Labour Organization, editor. United Nations Development Programme. New York: Sharing Innovative Experiences; 2011. p. 209-38.

25. Vargas I, Vázquez ML, Mogollón-Pérez AS, Unger J. Barriers of access to care in a managed competition model: lessons from Colombia. BMC Health Serv Res. 2010;10(1):297.

26. Giovanella L, Ruiz G, Feo O, Tobar S, Faria M. Health Systems in South America - Introduction. In: Instituto Suramericano de Gobierno de Salud (ISAGS) - Unión de Naciones Suramericanas (UNASUR), editor. Health Systems in South America: Challenges to the Universality, Integrality and Equity. p. 22-69.

27. Bossert T, Blanchet N, Sheetz S, Pinto D, Cali J, Cuevas RP. Comparative Review of Health System Integration in Selected Countries in Latin America: Inter-American Development Bank, Social Protection and Health Division; 2014 [cited 2014 Feb 25]. Available from: URL:http://idbdocs.iadb.org/ wsdocs/getdocument.aspx?docnum $=38336354$.

28. Cotlear D, Gómez-Dantés O, Knaul F, Atun R, Barreto, Ivana C H C, Cetrángolo O, Cueto M, Francke P, Frenz P, Guerrero R, Lozano R, Marten R, Sáenz R. Overcoming Social Segregation in Health Care in Latin America [Universal Health Coverage in Latin America 2]: The Lancet; 2014 [cited 2014 Dec 30]. Available from: URL:http://www.thelancet.com/journals/lancet/ article/PIIS0140-6736\%2814\%2961647-0/abstract.

29. lunes R, Cubillos-Turriago L, Escobar M. Universal Health Coverage and Litigation in Latin America [A regular series of notes highlighting recent lessons emerging from the operational and analytical, Number 178 (July 2012)]: The World Bank; 2012 [cited 2014 Jun 8]. Available from: URL:https:// openknowledge.worldbank.org/handle/10986/13072.

30. Francke P. Peru's Comprehensive Health Insurance and New Challenges for Universal Coverage [Universal Health Coverage Studies Series (UNICO) No. 11]: The World Bank; 2013 [cited 2014 Feb 25]. Available from: URL:http:// www.worldbank.org/en/topic/health/publication/universal-health-coveragestudy-series

31. Superintendencia de Salud Chile. Modalidad Libre Elección o M.L.E.; 2017 [cited 2017 Jan 17]. Available from: URL:http://www.supersalud.gob.cl/difusion/665/ w3-propertyvalue-2383.html.

32. Rathe M. Dominican Republic: Can universal coverage be achieved? [World Health Report 2010, Background Paper 10]: World Health Organization; 2010 [cited 2014 Mar 3]. Available from: URL:http://www.who.int/healthsystems/ topics/financing/healthreport/DR_No10.pdf.

33. Class D, Cavagnero E, Rajkumar AS. Health Financing Profile - Peru: Ministry of Health, Peru; The World Bank; 2013 [cited 2014 May 3]. Available from: URL:http://documents.worldbank.org/curated/en/242851468099278957/ Peru-Health-financing-profile.

34. Seinfeld J, Montañez V, Besich N. The Health Insurance System in Peru: Towards a Universal Health Insurance: Global Development Network; 2013 [cited 2014 Feb 25]. Available from: URL:http://www.gdn.int/admin/uploads/ editor/files/GDN_PEMRP_CIUP_PS_Health.pdf.

35. Núñez J, Zapata JG, Castañeda C, Fonseca M, Ramírez J. La Sostenibilidad Financiera del Sistema de Salud de Colombia: Dinámico del gasto y principales retos de cara al futuro: Fedesarollo; 2012 [cited 2014 Mar 3]. Available from: URL: http://www.fedesarrollo.org.co/wp-content/uploads/2011/08/La-sostenibilidadfinanciera-del-Sistema-de-Salud-Colombiano-Libro-Sura-Final-20121.pdf.

36. Knaul FM, González-Pier E, Gómez-Dantés O, García-Junco D, ArreolaOrnelas H, Barraza-Lloréns M, et al. The quest for universal health coverage: achieving social protection for all in Mexico. Lancet. 2012;380(9849):1259-79.

37. Lakin J. Mexico's Health System: More Comprehensive Reform Needed. PLoS Med. 2009;6(8):e1000130.
38. Scott J. Seguro Popular Incidence Analysis: Centro de Investigación y Docencia Económicas; 2006 [cited 2014 May 4]. Available from: URL:http:// siteresources.worldbank.org/INTMEXICOINSPANISH/Resources/NollIChapter3.pdf.

39. Xu K. Designing Health Financing Systems to Reduce Catastrophic Health Expenditure [Technical Brief for Policy-Makers]: World Health Organization; 2005 [cited 2014 Jun 8]. Available from: URL:http://www.who.int/health_ financing/documents/dp_e_05_2-distribution_of_health_payments.pdf.

40. World Health Organization. Distribution of health payments and catastrophic expenditures: Methodology [Discussion Paper 2]; 2005 [cited 2014 Jun 8]. Available from: URL:http://www.who.int/health_financing/ documents/dp_e_05_2-distribution_of_health_payments.pdf.

41. Evans D, Hsu J, Boerma T. Universal health coverage and universal access. Bull World Health Organ. 2013;91:546-546A.

42. Dannreuther C, Gideon J. Entitled to Health? Social Protection in Chile's Plan AUGE. Dev Chang. 2008;39(5):845-64.

43. Valdivia M. Etnicidad como determinante de la inequidad en salud materno-infantil en el Perú. In: Hernández Bello A, Rico de Sotelo C, editors. Protección social en salud en América Latina y el Caribe: Investigación y políticas. Ottawa [Ont.], Bogatá [Columbia]: Centro Internacional de Investigaciones para Dessarrollo/International Development Research Centre; Pontificia Universidad Javeriana; 2011. p. 121-58.

44. Hernández Bello A, Vega Romero R, Gutiérrez Bonilla ML. Retos para una protección social integral: vulerabilidad y exclusión de la población desplazada en Colombia. In: Hernández Bello A, Rico de Sotelo C, editors. Protección social en salud en América Latina y el Caribe: Investigación y políticas. Ottawa [Ont.], Bogatá [Columbia]: Centro Internacional de Investigaciones para Dessarrollo/ International Development Research Centre; Pontificia Universidad Javeriana; 2011. p. 235-88.

45. Saldarriaga ÁC, Nieto López E, Mejía Ortega LM. Factores relacionados con el no aseguramiento en salud de los trabajadores cesantes en la ciudad de Medellín, Colombia, 2007. In: Hernández Bello A, Rico de Sotelo C, editors. Protección social en salud en América Latina y el Caribe: Investigación y políticas. Ottawa [Ont.], Bogatá [Columbia]: Centro Internacional de Investigaciones para Dessarrollo/International Development Research Centre; Pontificia Universidad Javeriana; 2011. p. 289-318.

46. Montenegro-Torres F. Costa Rica Case Study: Primary Health Care Achievements and Challenges within the framework of the Social Health Insurance: The World Bank; 2013 [cited 2014 Mar 3]. Available from: URL: http://www-wds.worldbank.org/external/default/WDSContentServer/WDSP/ IB/2013/02/01/000425962_20130201121943/Rendered/PDF/ 749620NWPOCOSTO0Box374316B00PUBLIC0.pdf.

47. Missoni E, Solimano G. Towards Universal Health Coverage: the Chilean experience [World Health Report 2010, Background Paper 4]: World Health Organization; 2010 [cited 2014 Mar 3]. Available from: URL:http:// digicollection.org/hss/documents/s18282en/s18282en.pdf.

48. Vega J, Frenz P. Latin America: Priorities for Universal Health Coverage [Comment]: The Lancet; 2014 [cited 2014 Dec 31]. Available from: URL: http://www.thelancet.com/series/latin-america-UHC.

49. Zúñiga-Brenes MP, Vargas JR, Vindas A. Out-of-pocket and Catastrophic Health Expenditures Puzzle: The Costa Rican experience [Financiamiento en Salud y Protección Social en América Latina y el Caribe]: International Development Centre (Ottawa, Canada); Fundación Mexicana para la Salud; 2010 [cited 2014 Apr 6]. Available from: URL:http://www.funsalud.org.mx/ competitividad/financiamiento/Documentos/Working\%20paper\%20uno/ Costa\%20Rica\%20WP1.pdf.

50. The World Bank. GDP per capita (current US\$); 2014 [cited 2014 Feb 8]. Available from: URL:http://data.worldbank.org/indicator/NY.GDP.PCAP.CD.

51. United Nations Statistics Division. Social Indicators: United Nations; 2014 [cited 2014 Jun 8]. Available from: URL:http://unstats.un.org/unsd/ demographic/products/socind/default.htm.

52. Fundación Milenio. Informe Nacional de Coyuntura: SUMI [27 of June of 2014]; 2014 [cited 2014 Dec 30]. Available from: URL:http://www.fundacionmilenio.org/Informe-Nacional-de-Coyuntura/coy-242-sumi.html.

53. Ministerio de Salud del Estado Plurinacional de Bolivia. Ley No. 475: Prestaciones de Servicios de Salud Integral del Estado Plurinacional de Bolivia [Presentation of the Ministry of Health of the Plurinational State of Bolivia]; 2014.

54. Presidente Constitucional del Estado Plurinacional de Bolivia. Decreto Supremo No 1984: Reglamento a la Ley N 475 de Prestaciones de Servicios de Salud Integral del Estado Plurinacional de Bolivia; 2014 [cited 2014 Dec 30]. Available from: URL:http://www.sobretodopersonas.org/ phocadownload/normasnac/DECRETO\%20SUPREMO\%201984.pdf. 
55. Fondo Nacional de la Salud Chile. Asegurados. Carentes de Recursos Tramo A; 2016 [cited 2016 Jan 20]. Available from: URL:https://fonasaweb.fonasa.cl/ portal_fonasa/site/artic/20140621/pags/20140621214701.html.

56. Superintendencia de Salud Chile. ¿Cómo se clasifican los beneficiarios de Fonasa según su tramo?; 2014 [cited 2014 Feb 8]. Available from: URL:http://www.supersalud.gob.cl/consultas/570/w3-article-6304.html.

57. Fondo Nacional de la Salud Chile. Asegurados. Carentes de Recursos Tramo A; 2016 [cited 2016 Jan 20]. Available from: URL:https://fonasaweb.fonasa.cl/ portal_fonasa/site/artic/20140621/pags/20140621214701.html.

58. Guerrero R, Gallego Al, Becerril-Montekio V, Vásquez J. Sistema de salud de Colombia. Salud Publica Mex. 2011:53(2):S144-55.

59. Secretería General de la Alcaldía Mayor de Bogotá D.C. Acuerdo 415 de 2009 Consejo Nacional de Seguridad Social en Salud; 2009 [cited 2014 Feb 25]. Available from: URL:http://www.alcaldiabogota.gov.co/sisjur/normas/ Norma1.jsp?i=37351

60. Ministerio de las Tecnologías de la Información y las Comunicaciones. Inscripción al régimen subsidiado de salud [Alcaldía de Florida]; 2014 [cited 2014 Feb 25]. Available from: URL:https:/www.gobiernoenlinea.gov.co/web/ guest/home\%3Bisessionid =611F9D69F5E0B5C530AC1CFD20818707?p_p_id = GovBuilderPdfServicesViewer_WAR_govservicesviewerportlet\&p_p_lifecycle $=0 \& p \_p \_s t a t e=$ exclusive\&p_p_mode $=$ view $\& \_$GovBuilderPdfServicesViewer_ WAR_govservicesviewerportlet_serviceld $=13112$.

61. Consejo Nacional de Seguridad Social. Reglamento del Régimen Subsidiado del Sistema Dominicana de Seguridad Social; 2003 [cited 2014 Feb 25]. Available from: URL:http://www.tss.gov.do/pdf/regla_ regimen_sub.pdf.

62. Sistema Ünico de Beneficiarios. Qué es el SIUBEN? [Gobierno Dominicano]; 2014 [cited 2014 Feb 25]. Available from: URL:http://www.siuben.gob.do/lainstituci\%C3\%B3n/\%C2\%BFqu\%C3\%A9-es-el-siuben.aspx.

63. Rathe M, Moliné A. Sistema de salud de República Dominicana. Salud Publica Mex. 2011;53(2):S255-64.

64. Seguro Popular. Regimenes Estatales: Comissión Nacional de Protección Social en Salud; 2012 [cited 2014 Feb 25]. Available from: URL:http://www. seguro-popular.salud.gob.mx/index.php?option = com_content $\&$ view $=$ article\&id $=41 \&$ temid $=8$.

65. Superintendencia Nacional de Aseguramiento en Salud. La Ley Marco de Aseguramiento Universal en Salud: Ley N² 29344; 2014 [cited 2014 Feb 25]. Available from: URL:http://app3.sunasa.gob.pe/Temp/Ley_29344. Aseguramiento_Universal_en_Salud.pdf.

66. Ministerio de Desarollo e Inclusión Social. Sistema de Focalización de Hogares [cited 2014 Feb 25]. Available from: URL:http://www.mef.gob.pe/ contenidos/presu_publ/capacita/1_present_ULF.pdf.

67. Asamblea General. Ley N 18.596; 2009 [cited 2014 Jun 8]. Available from: URL:http://www2.ohchr.org/english/bodies/cat/docs/AnexoXXIII_Ley18596.pdf.

68. Aran D, Laca H. Sistema de salud de Uruguay. Salud Publica Mex. 2013;53(2): S265-74.

69. Administración de los Servicios de Salud del Estado. Afiliación Gratuita; 2014 [cited 2014 Feb 25]. Available from: URL:http://www.asse.com.uy/uc_6418_1.html.

70. Asamblea Legislativa Plurinacional. Bolivia: Ley $N^{\circ}$ 475, 30 de diciembre de 2013 [Ley de prestaciones servicios de salud integral del Estado Plurinacional de Bolivia]; 2013 [cited 2014 Jun 8]. Available from: URL:http:// www.lexivox.org/norms/BO-L-N475.xhtml.

71. Joint Learning Network for Universal Health Coverage. Chile: National Health Fund (FONASA); 2014 [cited 2014 Mar 3]. Available from: URL:http:// www.jointlearningnetwork.org/content/national-health-fund-fonasa.

72. World Health Organization. Success Stories of Health Financing Reforms for Universal Health Coverage: Chile; 2012 [cited 2014 Mar 3]. Available from: URL:http://www.who.int/providingforhealth/PH4_Chile_2.pdf.

73. Alcaldía Mayor de Bogotá. Sistema General de Participaciones SGP; 2014 [cited 2014 Mar 3]. Available from: URL:http://impuestos.shd.gov.co/portal/ page/portal/portal_internet_sdh/tesoreria/ingresos_tes/SGP.

74. Ministerio de Salud y Protección Social. Unidad de Pago por Capitación [República de Colombia]; 2014 [cited 2014 Mar 3]. Available from: URL: http://www.minsalud.gov.co/salud/POS/Paginas/Proyecto-POS-UPC.aspx.

75. Rocío-Sáenz Md, Bermúdez JL, Acosta M. Universal Health Coverage in a Middle Income Country: Costa Rica [World Health Report, Background Paper, 11]: World Health Organization; 2010 [cited 2014 Feb 25]. Available from: URL:http://www. who.int/healthsystems/topics/financing/healthreport/CostaRicaNo11.pdf.

76. Durán Valverde F. Innovaciones en la extensión de la cobertura del seguro social a los trabajadores independientes: Experiencias de Brazil, Cabo Verde, Colombia, Costa Rica, Ecuador, Filipinas, Francia y Uruguay: International
Labour Organization; 2013 [cited 2015 Jan 5]. Available from: URL:http:// labordoc.ilo.org/record/459874

77. Tuluy HA, Brook PJ, Hansen KE, Godinho J, Gragnolati M, Perez LO. Republic of Uruguay: Integrated National Health System; Analysis of the Governability of the SNIS Benefit Plan (PIAS)s: The World Bank; 2012 [cited 2014 Mar 3]. Available from: URL:http://www-wds.worldbank.org/external/default/ WDSContentServer/WDSP/B/2013/09/23/000442464_20130923100243/ Rendered/PDF/800840ESWOUrug000PUBLIC00Box379829B.pdf.

78. Aguilar Rivera, Ana Mylena, Xu K, Carrin G. The Bolivian Health System and its Impact on Health Care Use and Financial Risk Protection: World Health Organization; 2006 [cited 2014 Dec 30]. Available from: URL:http://www. who.int/health_financing/Bolivian_health_system.pdf.

79. Joint Learning Network for Universal Health Coverage. Colombia: General System of Social Security in Health; 2014 [cited 2014 Mar 3]. Available from: URL:http://www.jointlearningnetwork.org/content/general-system-socialsecurity-health.

80. Vargas-Zea N, Castro H, Rodríguez-Páez F, Téllez D, Salazar-Arias R Colombian Health System on its Way to Improve Allocation Efficiency Transition from a Health Sector Reform to the Settlement of an HTA Agency. Value Health Reg Issues. 2012;1(2):218-22.

81. Rathe M, Knaul F, Yerramilli P. Financing Cancer Care and Control in Dominican Republic [DCP3 Volume 6, Chapter 15 Supplement]: Harvard Global Equity Initiative; 2014 [cited 2016 Jul 14]. Available from: URL:hgei.harvard.edu/ fs/docs/icb.topic910623.files/DCP3 Input -Dominican Republic.pdf.

82. Superintendencia de Salud Chile. Patologías garantizadas AUGE; 2016 [cited 2016 Aug 4]. Available from: URL:http://www.supersalud.gob.cl/difusion/572/ w3-propertyname-501.html.

83. Ministerio de Salud de Colombia. ABC de la Unificación del POS; 2012 [cited 2014 Dec 31]. Available from: URL:http://www.minsalud.gov.co/Paginas/ ABC\%20de\%20la\%20Unificaci\%C3\%B3n\%20del\%20POS.aspx.

84. Cooperativa Empresa Solidaria de Salud y Desarrollo Integral (COOSALUD EPS-S). Régimen de Copagos; 2014 [cited 2014 Apr 3]. Available from: URL http://www.coosalud.com/index.php/afiliados/coopago/.

85. Ministerio de Salud y Protección Social. Decreto Número 1683 de 2013; 2013 [cited 2014 Mar 3]. Available from: URL:http://www.consultorsalud. com/attachments/article/0/Decreto\%201683\%20de\%202013\%20-\%20 portabilidad\%20nacional\%20de\%20salud.pdf.

86. Centro de Desarrollo Estratégico e Información en Salud y Seguridad Social (CENDEISSS). Reglamento del seguro de salud; 2014 [cited 2014 Mar 3]. Available from: URL:http://www.cendeisss.sa.cr/etica/reglamentosalud.pdf.

87. Rodríguez I. Ebais y clínicas mejorarán sus procesos para atender infartos: La Nación; 2013 [cited 2014 Mar 3]. Available from: URL:http://www.nacion. com/vivir/medicina/Ebais-clinicas-mejoraran-procesos-infartos_0_ 1369063156.html.

88. Di Mclntyre. Country Case Study: Universal Health Insurance in Costa Rica: University of Cape Town, Health Economics Unit; 2006 [cited 2014 Mar 3]. Available from: URL:http://uct-heu.s3.amazonaws.com/10FinancingCostaRica.pdf.

89. Presidente de la República Dominicana. Decreto Número 74-03: Reglamento sobre el Seguro Familiar y el Plan Básico de la Salud; 2003 [cited 2014 Jun 8]. Available from: URL:http://www.comisionadodejusticia. gob.do/phocadownload/Biblioteca_Virtual/Salud/Decreto\%2074-03,\%20 establece\%20el\%20Reglamento\%20sobre\%20el\%20Seguro\%20Fam iliar\%20de\%20Salud\%20y\%20el\%20Plan\%20Basico\%20de\%20Salud.pdf.

90. Laurell, Asa Cristina. Impacto del seguro popular en el sistema de salud mexicano. Buenos Aires: Consejo Latinoamericano de Ciencias Sociales (CLACSO); 2013

91. Gobierno del Distrito Federal. Portabilidad 32 × 32: Sistema de Protección Social en Salud, Seguro Popular; 2014 [cited 2014 Mar 3]. Available from: URL:http://www.salud.df.gob.mx/ssdf/seguro_popular/index/portabilidad.php.

92. Sollazzo A, Berterretche R. El Sistema Nacional Integrado de Salud en Uruguay y los desafíos para la Atención Primaria; 2011 [cited 2014 May 3]. Available from: URL:http://www.redalyc.org/articulo.oa?id =63019110021.

93. Mathauer I, Wittenbecher F. Hospital payment systems based on diagnosisrelated groups: experiences in low- and middle-income countries. Bulletin of the World Health Organization 2013 [cited 2013 Apr 4]; (91):746-756A. Available from: URL:http://www.who.int/bulletin/volumes/91/10/12-115931/en/.

94. Instituto Suramericano de Gobierno de Salud (ISAGS) - Unión de Naciones Suramericanas (UNASUR), editor. Health Systems in South America: Challenges to the Universality, Integrality and Equity. Available from: URL: http://www.isags-unasur.org/uploads/biblioteca/2/bb\%5B8\%5Dling\%5B3\%5 Danx\%5B8\%5D.pdf. 
95. Fondo Nacional de la Salud Chile. Estadísticas Institucionales [Boletin Estadístico 2011-2012]; 2014 [cited 2014 Apr 8]. Available from: URL: http://www.fonasa.cl/wps/wcm/connect/Internet/SA-General/Informacion + Corporativa/Estadisticas + Institucionales/.

96. Pérez J. Una mirada al Seguro Familiar de Salud: Observatorio Político Dominicano; 2013 [cited 2014 Jun 10]. Available from: URL:http://www.opd. org.do/index.php?view $=$ article\&catid $=112 \% 3$ Aanalisis-pp\&id $=1279 \% 3$ Auna-mirada-al-seguro-familiar-de-salud\&tmpl $=$ component\&print $=1$ \& layout $=$ default\&page $=$ \&option $=$ com_content .

97. Consejo Nacional de Seguridad Social. La Seguridad Social Avanza en República Dominicana. Informa - Organo Informativo del Consejo Nacional de Seguridad Social; 2016(24)

98. Xu K, Saksena P, Jowett M, Indikadahena C, Kutzin J, Evans D. Exploring the thresholds of health expenditure for protection against financial risk [World Health Report 2010, Background Paper 19]: World Health Organization; 2010 [cited 2015 Jan 5]. Available from: URL:www.who.int/healthsystems/topics/ financing/healthreport/19THE-thresv2.pdf.

99. Knaul FM, Wong R, Arreola-Ornelas H, editors. Financing Health in Latin America: Household Spending and Impoverishment: Harvard University Press; 2012. (Volume 1) [cited 2014 Mar 3]. Available from: URL:http://www. idrc.ca/EN/Documents/Financing-Health-in-Latin-America-Volume-1.pdf.

100. Wagstaff A, Cotlear D, Hoang-Vu Eozenou P, Buisman LR. Measuring Progress Towards Universal Health Coverage: With An Application to 24 Developing Countries [Policy Research Working Paper 7470]: World Bank Group; 2015 [cited 2016 Jul 14]. Available from: URL:documents.worldbank. org/curated/en/2015/11/25239709/measuring-progress-towards-universalhealth-coverage-application-24-developing-countries

\section{Submit your next manuscript to BioMed Central and we will help you at every step:}

- We accept pre-submission inquiries

- Our selector tool helps you to find the most relevant journal

- We provide round the clock customer support

- Convenient online submission

- Thorough peer review

- Inclusion in PubMed and all major indexing services

- Maximum visibility for your research

Submit your manuscript at www.biomedcentral.com/submit

) Biomed Central 